\title{
O MURO ESTADUNIDENSE: UMA GEOPOLÍTICA DO DESENCONTRO
}

\author{
Célio Augusto da Cunha ${ }^{1}$ \\ Rafael Rodrigues da Franca ${ }^{2}$
}

"Mas o que são os muros senão interfaces disfarçadas, camuflagens de ambientes mais amplos, insinuações concretas para a reflexão sobre a liberdade ou sobre a transgressão libertadora?" (HISSA, 2002).

\section{1- INTRODUÇÃO}

Trabalhos relacionados à produção de fronteiras constituem, no âmbito da geografia, temática tradicional. Entretanto, por razões históricas e epistemológicas, estudos de geografia política tornaram-se mais raros - não por mero acaso - após a Segunda Guerra ${ }^{3}$. Consequentemente, escassearam-se também, os debates e as pesquisas sobre fronteiras. Todavia, estão sendo retomados, mais recentemente, alguns estudos dessa natureza.

Determinadas pesquisas geográficas estão vinculadas, assim, aos rearranjos territoriais desenvolvidos nesta atual fase do modo de produção capitalista ${ }^{4}$. Inclusive, novos muros entre povos e países são erguidos, fronteiras segregacionistas estão sendo criadas e reforçadas. Em meados dos anos de 1990, na fronteira MEX-EUA, iniciou-se a construção de um

\footnotetext{
${ }^{1}$ Professor Assistente do Departamento de Geografia da UFMG

${ }^{2}$ Bolsista PAE (2003-2004), discente do curso de graduação em Geografia da UFMG

${ }^{3}$ Sobre os efeitos deletérios de uma "geopolítica nazista" na produção do conhecimento geográfico (mais especificamente, na órbita da Geografia Política) ver COSTA, Wanderley Messias. Geografia Política e Geopolítica. São Paulo: Hucitec/USP, 1992.

${ }^{4}$ Nesse contexto do capitalismo "pós-fordista/pós-Guerra Fria", importantes estratégias econômicas e espaciais desenvolvem-se como, por exemplo, a ampliação e o aprofundamento da União Européia, a consolidação do NAFTA, a desregulamentação de vários direitos trabalhistas, a flexibilização produtiva, etc.
}

Cadernos do Leste

Artigos Científicos

Belo Horizonte, Edição Especial, 2000 a 2008 
extenso muro. Camuflado em parte pelas lembranças do Muro de Berlim, a sua aparência, no entanto, após dez anos de existência, tornou-se muito mais evidente. Hoje, parcialmente em razão dessa maior visibilidade emergem questionamentos diversos, muitos deles preocupados em romper com a simples aparência dos processos.

Objetivando-se, também abordar algumas das relações socioespaciais pertinentes ao muro estadunidense (e à referida fronteira) definiu-se, então, investigar:

- Se o propósito geopolítico original do Muro tem alcançado o êxito esperado pelos seus idealizadores, ao longo desses anos;

- Possíveis contradições entre alguns valores éticos genericamente atribuídos ao muro e as políticas dos Estados-Nacionais envolvidos no controle da fronteira;

- A geopolítica do Estado mexicano na fronteira sul (México-Guatemala e Belize).

Preocupações como essas, por exemplo, são merecedoras de investigações geográficas, mesmo que os resultados sejam, ainda, parciais e preliminares. Portanto, neste trabalho realizou-se, inicialmente, uma reflexão envolvendo concepções de fronteira, incluindo, conotações pertinentes ao atual contexto da globalização. A segunda parte focalizou a formação das fronteiras norte e sul do México destacando, entre outros processos, os seus elementos contraditórios. Efetuou-se, na terceira e última parte desse artigo, uma caracterização e uma problematização geográfica do Muro.

\section{2- LIMITES TERRITORIAIS E CONCEITUAIS DAS FRONTEIRAS NO INÍCIO DO SÉCULO XXI}

Reinvidicações por autonomia territorial, a exemplo do conflito entre a Rússia e a República da Chechênia; enclaves, como a base de Guantánamo em Cuba ou o da região de Nagorno-Karabakh no Azerbaijão; ou mesmo, a questão da Caxemira ${ }^{5}$ são apenas alguns dos diversos confrontos internacionais que indicam, entre outros aspectos, a relevância das fronteiras nacionais no atual cenário mundial. Tal afirmativa parece-nos óbvia, porém se

\footnotetext{
${ }^{5}$ Há complexos processos envolvendo a questão da Caxemira. A guerra entre o Paquistão e a Índia, que disputam esta região, coexiste, por exemplo, com movimentos de guerrilha que lutam pela emancipação do território (constituição de um novo país).
}

Cadernos do Leste

Artigos Cientificos

Belo Horizonte, Edição Especial, 2000 a 2008 
defrontada com discursos recentes que, veementemente, insistem em frisar que no contexto da globalização vigente há, por exemplo, o desaparecimento das fronteiras e do Estado Nacional, estabelece-se, então, uma contradição eminente.

Moura $(2000)^{6}$ considera que as fronteiras estão, cada vez mais, adquirindo uma outra expressão e não tendem, de forma alguma, ao desaparecimento.

“(...)Essa retórica vem sustentando o entendimento de que as fronteiras são dispensáveis, de que já nem existem. No entanto, o mundo nunca viveu tanto controle sendo exercido em seus tantos fragmentos." 7

Diante desta contradição - que em parte é resultante das concepções diversas sobre globalização $^{8}$ - torna-se interessante destacar o fato de que o conceito de fronteiras, muitas vezes, está sendo aplicado de maneira indiscriminada e reducionista. Não que se defenda um conceito único e objetivo de fronteira, porque tal procedimento se constituiria em outro grave equívoco. Entretanto, existem alguns fundamentos de natureza geográfica que não podem ser negligenciados, quando as fronteiras são enfocadas. Por conseguinte, torna-se no mínimo cuidadoso e responsável reconhecer, por exemplo, que "queda de barreiras alfandegárias" não corresponde ao "fim das fronteiras"."As fronteiras do capital constituem tão somente uma modalidade, ou mesmo, uma particularidade diante de concepções mais amplas de fronteira.

\footnotetext{
${ }^{6}$ MOURA, R. Fronteiras invisíveis: o território e seus limites. IN Território/LAGET, UFRJ - ano V, $\mathrm{n}^{\circ} 9-$ RJ : UFRJ, 2000.

${ }^{7}$ MOURA, R. op. cit. p. 86.

${ }^{8}$ Rogério Haesbaert discute sobre as diferentes concepções de globalização em seu texto "Questões e mitos sobre a globalização" IN Fronteiras e espaço global; STROHAECKER, T. et al. (org.). Porto Alegre, AGB, 1998. (11-16). Hindenburgo Pires apresenta também interpretações (ou correntes teóricas) da globalização. Ver PIRES, H. F. "Ethos" e mitos do pensamento único globaltotalitário. SP: AGB; Terra Livre; $\mathrm{n}^{\circ} 16$, 2001. (153-168).

${ }^{9}$ Além do reducionismo teórico embutido nesta visão economicista de fronteira, é importante lembrar que políticas deliberadamente protecionistas convivem, por exemplo, com as leis internas dos mercados comuns mantendo-se, assim, antigas barreiras comerciais e recriando-se, também, novas fronteiras, como as supranacionais dos megablocos regionais. Portanto, mesmo concebendo-se a fronteira apenas como uma barreira comercial é notável a sua persistência e a sua metamorfização em escala ampliada. Sobre esta questão, Martin, em uma de suas obras, elaborou um capítulo intitulado “É o fim das fronteiras?" Ver MARTIN, A. Fronteira e nação. SP: Contexto, 1998.
}

Cadernos do Leste

Artigos Cientificos

Belo Horizonte, Edição Especial, 2000 a 2008 
Autores vinculados aos estudos de geopolítica e/ou de geografia política realizaram inúmeras classificações e diferentes modos de conceber as fronteiras, suas funções e seus limites. Lord Curzon, citado por Miyamoto (1998), considerou em seus estudos três tipos de fronteiras: astronômica, geométrica e de referência ${ }^{10}$. Superando a concepção clássica que divide as fronteiras em artificiais e naturais, Camilo Vallaux, no início do século XX, apresentou uma proposta classificando as fronteiras em esboçadas, mortas e vivas. Quando os limites extensos, de uma determinada região, são traçados de maneira pouco rigorosa, pode-se aplicar o conceito de fronteira esboçada. Esta situação foi mais frequente durante o período colonial e mais recorrente em regiões pouco povoadas ${ }^{11}$. Contrariamente, as fronteiras mortas são aquelas plenamente demarcadas e estabelecidas, e que também são aceitas pelas populações de ambos territórios. Para Andrade (2000), neste caso, a separação entre os territórios é apenas formal, devido ao elevado grau de integração e estabilidade. As fronteiras vivas manifestam relações de tensão, de conflito na região de contato entre as territorialidades envolvidas. $^{12}$

Mélo (1997) adverte para a necessidade de se ultrapassar a noção de "fronteira como um limite burocrático-administrativo entre municípios, regiões, unidades da Federação ou mesmo entre Estados nacionais" $" 13$ Para o autor, as fronteiras são muito mais do que isso, pois estão permeadas de movimento, de contradições, de sentimentos e símbolos. Para Milton

\footnotetext{
${ }^{10}$ As fronteiras, nesta classificação, são sugeridas por limites oficiais (Estado) de demarcação. As fronteiras geométricas seguem, simplesmente, a lógica das retas (a exemplo das divisões entre vários estados dos E.U.A.); as linhas das fronteiras astronômicas consideram os valores dos meridianos e os paralelos; e as de referência seguem "a uma distância conveniente" cursos de rios, cadeias de montanhas, etc. Ver MIYAMOTO, S. Geopolítica e poder no Brasil. SP: Papirus, 1995; p. 172

11 “(...) muitas das fronteiras com as Guianas, com a Venezuela e a Colômbia, são desse tipo, são linhas traçadas em florestas de difícil penetração". ANDRADE, M. C. A trajetória do Brasil (de 1500 a 2000). SP: Contexto, 2000; p. 60. Persiste até hoje, a disputa entre Venezuela e Guiana pela região situada entre os rios Essequibo e Cuyuni-amakura, que compreende cerca de 2/3 (85.000 km quadrados) do território da Guaina. ${ }^{12}$ Quanto aos três conceitos mencionados, a interpretação de Andrade difere parcialmente da de Miyamoto op cit. Ver ANDRADE, M. C. op.cit.; p. 60.

${ }^{13}$ Ver MÉLO, J. L. B. Reflexões conceituais sobre fronteira. IN Fronteiras na América Latina - Espaços em transformação. Porto Alegre: UFRGS / Fundação de Economia e Estatística, 1997; p. 68-69.
}

Cadernos do Leste

Artigos Científicos

Belo Horizonte, Edição Especial, 2000 a 2008 
Santos, citado por Mélo (1997) “(...) as fronteiras não são algo acabado, são momentos de um processo." 14

Segundo Atencio, citado por Miyamoto (1998), o limite "apresenta-se como uma linha divisória de espaços; a palavra fronteira dá a ideia dos lugares onde têm contato os elementos que convivem em diferentes espaços" ${ }^{\prime 15}$ Para Hissa (2002), os conceitos de limite e de fronteira se misturam, interpenetram-se. ${ }^{16}$ Esta fusão, em parte, justifica-se pela própria dinâmica social concernente à produção dos limites e fronteiras, ou seja, pela característica móvel e mutável de ambos.

“O que foi concebido para "por fim”, para delimitar territórios com precisão como se fosse uma linha divisória, espraia-se em uma zona de interface e de transição entre dois mundos tomados como distintos. Assim, o limite transforma-se em fronteira." 17

Hissa (2002) salienta que "a mutação da própria natureza dos limites e das fronteiras é uma resposta às transformações políticas, econômicas, culturais." ${ }^{11}$ Miyamoto (1998) destaca uma passagem de Ratzel, reforçando, também, a condição inerente de dinâmica e mutabilidade das fronteiras:

"A fronteira é função de um duplo movimento entre dois povos: é um meio-termo, um organismo periférico que avança ou recua dando a medida da força ou da fraqueza da sociedade que limita." 19

Mélo (1997), citando Edgar Morin, ressalta também essa característica particular da fronteira:

\footnotetext{
${ }^{14}$ Ver MÉLO, J. L. B. op. cit. p. 69

${ }^{15}$ Ver MIYAMOTO, S. op. cit. p.170. O autor sintetiza ainda: "A fronteira abrange, portanto, uma zona não delimitada rigidamente, na medida em que o limite não é de forma alguma permanente; serve para dividir dois territórios e constitui-se sempre em medidas artificiais, mesmo que elementos naturais sejam utilizados para servir como linhas". Ibidem, p. 174.

${ }^{16}$ HISSA, C. E. V. A mobilidade das fronteiras: inserções da geografia na crise da modernidade. BH: UFMG, 2002; p. 35.

${ }^{17}$ Ibidem p. 36. Hissa reafirma, também, o caráter político das fronteiras e dos limites: “(...) os limites nos territórios são incontestavelmente políticos e pressupõem a projeção do trabalho e da cultura.” Idem. p. 37.

${ }^{18}$ Ibidem. p. 37

${ }^{19}$ MIYAMOTO, S. op. cit. p. 170.
}

Cadernos do Leste

Artigos Científicos

Belo Horizonte, Edição Especial, 2000 a 2008 
“(...) a fronteira é aquilo que, simultaneamente, proíbe e autoriza a passagem, aquilo que fecha e aquilo que abre."20

Mélo (1997) classifica as fronteiras como materiais e simbólicas. As primeiras são aquelas identificáveis em mapas políticos tradicionais e as segundas são as fronteiras que segregam indivíduos, grupos sociais, povos e nações. Tratam-se, portanto, das fronteiras do conhecimento, da dignidade, ou das fronteiras da miséria, do racismo, etc. ${ }^{21}$.

Contudo, pode-se pensar na fusão das fronteiras materiais e simbólicas, postuladas por José Mélo. O resultado se converteria em uma nova atribuição conceitual. Assim, relações de poder espacialmente materializadas e demarcadas quando combinadas com ações e reações psicológicas (ideologicamente definidas ou não), provenientes dos mais diversos segmentos populacionais acabam por resignificar a fronteira. Um novo teor é socialmente atribuído à fronteira, sem se perder de vista o seu condicionamento histórico. O Muro de Berlim, neste sentido, é emblemático.

Para Moura (1997), “o símbolo das fronteiras formais pode ser representado pelo Muro de Berlim: divisão autoritária de um espaço urbano contíguo(...)"22. A autora enfatiza que a fronteira formal não é a única, porém, salienta que "no sentido formal, fronteiras são o limite do exercício do poder" ${ }^{23}$. Linhas demarcatórias, barricadas, catracas e muros, por exemplo, definem recortes territoriais nas diferentes escalas e envolvem também relações sociais diversas.

Ao ser reproduzido na condição de obstáculo concreto (um muro, por exemplo), um determinado limite pode manifestar uma situação paradoxal: uma relação de poder em

\footnotetext{
${ }^{20}$ MÉLO, J. op. cit. p. 69.

${ }^{21}$ Sobre o assunto, ver detalhadamente o artigo do mesmo autor; MÉLO, J. op. cit.

${ }^{22}$ MOURA, R. Dos espaços sem fronteiras às fronteiras dos espaços. IN Fronteiras na América Latina Espaços em transformação. Porto Alegre: UFRGS / Fundação de Economia e Estatística, 1997; p. 96

${ }^{23}$ Ibibem. p. 96. Vale lembrar que as fronteiras não são produzidas apenas pelo Estado. As relações de poder que se manifestam no espaço transcendem o Estado. "É preciso dissipar a freqüente confusão entre Estado e poder. O poder nasce muito mais cedo, junto com a história que contribui para fazer". Raffestin (1993) citando Lefebvre. RAFFESTIN, C. Por uma geografia do poder. SP : Ática, 1993; p. 15.
}

Cadernos do Leste 
transformação. Pode, portanto, revelar a mudança de um poder legitimado em poder imposto, em violência. ${ }^{24}$ Para Hissa (2002),

"A fronteira, ao longo da história, pretendeu desenhar uma imagem de pedra e precisão: os muros são o seu símbolo, com toda a sua concretude. Entretanto, apesar da imagem de intransponibilidade, os muros são apenas camuflagens. (...) Também trata-se, paradoxalmente, de um ambiente dissimulado de integração (porque erguido na relação), transgressor, que pretende se apresentar como obstáculo". 25

\section{3- AS FRONTEIRAS MATERIAIS E SIMBÓLICAS DO MÉXICO}

$\mathrm{Na}$ fronteira dos EUA com o México, há muito mais do que o Rio Grande. Há um passado de conquistas, de guerras; um muro extenso e ostensivo; o "mundo desenvolvido" de um lado e o "subdesenvolvido" do outro ${ }^{26}$. Conflitos, protestos, migrações legais e clandestinas, sonhos e desilusões são alguns dos sentimentos e processos que comparecem nessa longa e diversa região fronteiriça. Uma fronteira recentemente "recosturada" pela construção do muro estadunidense.

Portanto, para contribuir com o difícil processo de compreensão atinente à produção do muro estadunidense, elaborou-se um breve histórico enfocando a formação das fronteiras mexicanas. Assim, inicialmente, efetivou-se o resgate de algumas interpretações históricogeográficas sobre a constituição das fronteiras sul e norte do México ${ }^{27}$.

24 “(...) a guerra, ou a violência em geral, é inclusive várias vezes um sintoma de perda de poder." Ver SOUZA, M. J. L. O território: sobre espaço e poder, autonomia e desenvolvimento. IN Geografia: conceitos e temas. CASTRO, E. et. al. (ogrs.) RJ : Bertrand Brasil, 1995; p. 78.

${ }^{25}$ HISSA, C. E. V. op. cit. p. 40.

${ }^{26}$ É importante atentar para o fato que o "mundo desenvolvido" também se revela no Sul e o chamado "subdesenvolvido" manifesta-se igualmente no Norte. Neste aspecto, vale refletir sobre os desdobramentos do NAFTA (North American Free Trade Agreement). O México, por exemplo, ascendeu significativamente no ranking das maiores economias do planeta, no entanto teve a quantidade de pobres aumentada de $16 \%$ para 58\%. Ver MASSAD, A. Sombrero na mão. IN: Revista FÓRUM, ${ }^{\circ}{ }^{\circ} 10 ;$ p. 12-15.

${ }^{27}$ Evidentemente que a abordagem deste trabalho, não é suficiente para o alcance total do processo de formação territorial das fronteiras Sul e Norte do México. Estudos históricos sobre a constituição social e

Cadernos do Leste

Artigos Cientificos

Belo Horizonte, Edição Especial, 2000 a 2008 


\section{A fronteira sul-mexicana: um novo muro?}

Há problemas fronteiriços entre a Guatemala e o México. Um deles, de natureza mais histórica, refere-se ao território de Chiapas. Outra questão problemática, envolvendo processos mais recentes, vincula-se à ação do Estado mexicano junto aos migrantes ilegais guatemaltecos que tentam ultrapassar os limites de fronteira dos dois países.

\section{Chiapas: território contestado}

Dentre os 31 estados federativos do México, o território de Chiapas talvez seja aquele que tenha adquirido maior notoriedade internacional nos últimos dez anos ${ }^{28}$ Contudo, o Zapatismo de Chiapas corresponde a uma manifestação (mais atual) de um longo processo muito mais abrangente de lutas, de desencontros, de construções e sofrimentos que marcam a complicada relação entre população e território - no México, como um todo (a exemplo da Revolução de 1910) e na região em questão.

Se atualmente há lutas regionais (populares) reivindicando junto ao Estado uma melhor inserção econômica e social de Chiapas no contexto nacional, a Guatemala, ainda hoje, reclama a propriedade desse território. Entretanto, Chiapas é um estado historicamente marginalizado pelo México, apesar de que esse sequer cogita discutir a respeito de uma suposta "devolução".

A questão entre Guatemala e México, envolvendo o território de Chiapas, tem origem no processo de constituição de alguns Estados independentes na América Central. A

política do México; diagnósticos sobre a sua inserção no NAFTA; estudos migratórios; etc. tornam-se nesse sentido necessários. Porém, há um vínculo direto entre a formação das fronteiras mexicanas principalmente a do norte - e a construção do referido muro.

28 Em 1994, um ano após o ingresso do México ao NAFTA, deflagrou-se em Chiapas uma rebelião (armada) de cunho popular. O Exército Zapatista de Libertação Nacional (EZLN), formado basicamente por índios camponeses, reivindicava melhorias sociais e econômicas para o estado (um dos mais pobres do país) e para sua população. Desde então, decisões políticas nacionais e supranacionais, necessariamente, passaram a considerar parte dos anseios dos filhos de Zapata. Além disso, esse movimento de característica localizada acabou por adquirir uma dimensão "globalizada" (no final dos anos 90, por exemplo, realizou-se em Chiapas, o I Encontro Intercontinental pela Humanidade e contra o Neoliberalismo). Ver Instituto de Investigaciones Económicas - Universidad Nacional Autónoma de México. Chiapas. México, D.F.: Era, 1997.

Cadernos do Leste

Artigos Cientificos

Belo Horizonte, Edição Especial, 2000 a 2008 
Capitania Geral da Guatemala, ao emancipar-se politicamente da metrópole espanhola, incorporou-se ao México em $1822{ }^{29}$. Entretanto, no ano seguinte (1823), foram criadas as Províncias Unidas da América Central (PUAC), havendo, então a desagregação em relação ao Império Mexicano. Porém, o território de Chiapas - que fazia parte da Capitania - foi anexado ao Império de Iturbide, no ano de 1824.

Chiapas, que se declarou independente da Espanha um pouco antes do que o México e a Capitania da Guatemala, colocava-se como território autônomo em relação a ambos:

"Los chiapanecos, - ellos mismos suelen decirlo, - no son ni mexicanos ni centro-americanos: son chiapanecos", 30

Para o Ministério da Educação Pública da Guatemala, no entanto, Chiapas incorporou-se ao México pela ação de força militar e por meio de deliberações parlamentares que envolviam representantes de segmentos das elites centro-americana e mexicana. Da mesma forma que ocorreram manifestações populares contrárias à anexação da Capitania da Guatemala ao Império mexicano, também havia descontentamentos - do "povo" e de boa parte das elites centro-americanas - referentes à apropriação de Chiapas pelo México. Os desdobramentos geopolíticos são conhecidos:

"La agregacion de Chiapas á los Estados-Unidos Mexicanos, fué obra de la violencia y de la intriga; de consiguiente no puede, no debe fundar un título de domínio." 31

Em 1838-39, contrariamente aos preceitos bolivarianos, as PUAC foram dissolvidas. Assim, a Confederação fragmentou-se em pequenas repúblicas: Honduras, El Salvador, Nicarágua, Costa Rica e Guatemala ${ }^{32}$. Em 1842, o México ocupou militarmente o território

${ }^{29}$ O Plano Iguala assegurava a manutenção das estruturas econômicas e sociais (do tipo coloniais) no México que, a partir de 1821, portanto, emancipava-se politicamente da Espanha. Ver POMER, L. As independências na América Latina. SP : Brasiliense, 1981.

${ }^{30}$ Retirado do livro intitulado Límites entre Guatemala y México. Centro Editorial "Jose de Pineda Ibarra". Ministerio de Educación Pública. Guatemala, 1964; p. 70. Há algumas semelhanças entre esse processo geopolítico de Chiapas e o do Texas: o Texas, inicialmente, proclamou-se independente (dos EUA e do México); porém, os processos de anexação aos respectivos países apresentam diferenças significativas.

${ }^{31}$ Límites entre Guatemala y México. op. cit., p. 71

${ }^{32}$ Em 1798, a Inglaterra assumiu, frente à Espanha, o controle da região que atualmente corresponde a Belize. Entretanto, no decorrer da fragmentação das Províncias Unidas da América Central, a Guatemala

Cadernos do Leste

Artigos Cientificos

Belo Horizonte, Edição Especial, 2000 a 2008 
de Soconusco, que originalmente pertencia a Chiapas. Consequentemente, os conflitos diplomáticos e as divergências entre o México e a nova nação da Guatemala ampliaram-se.

“Chiapas, sin embargo, entró en la confederación mejicana sin que Centro-América aceptase como derecho aquel suceso.(...) En 1842, bajo el especioso pretexto de que en Soconusco se refugiaban emigrados, el General Santa Ana ocupó el territorio, y se le hizo correr le suerte de Chiapas, tratando de sincerar la ocupación y de absolverla, com un voto emitido bajo de los dominadores." 33

Somente, em 1882 (em Nova Iorque), firmou-se um Tratado de limites que destinava ao México o direito internacional por Chiapas; além de definir mais precisamente os limites entre Guatemala e México. O Artigo $1^{\circ}$ desse Tratado, é muito explícito:

“Artículo $1^{\circ}$ - La República de Guatemala, renuncia para siempre los derechos que juzga tener al territorio del Estado de Chiapas y su distrito de Soconusco, y en consecuencia, considera dicho territorio como parte integrante de los Estados Unidos Mejicanos." 34

\section{Uma fronteira violada.}

Recentemente, uma comissão nacional da Guatemala (que trata de assuntos migratórios $)^{35}$ solicitou ao Presidente Fox, providências para que sejam alteradas as relações que são, no momento, estabelecidas na fronteira desse país com o México.

Os problemas levantados se concentraram, basicamente, em torno de dois processos: 1) garantias trabalhistas para os migrantes guatemaltecos, especificamente no Estado de Chiapas e, 2) proteção dos defensores dos direitos humanos na região de fronteira.

alega ter sofrido perdas territoriais para a colônia inglesa. Em 1859, Grã-Bretanha e Guatemala assinaram um tratado que definiria a linha demarcatória da fronteira. Por uma série de razões, o tratado, foi, a posteriori rejeitado pela Guatemala. Em 1975, o litígio fronteiriço acirrou-se, contribuindo assim, para a emancipação política de Belize (que se tornou um país reconhecido pela ONU somente em 1981). Ainda hoje, a Guatemala reivindica Belize como sendo sua porção territorial. Segundo Aristides Royo (expresidente do Panamá), em 2000, as Forças Armadas da Guatemala realizaram várias incursões em Belize. Reclamavam a concessão da metade do território, apesar de que, em 1991, a Guatemala reconheceu oficialmente a independência de Belize. Ver Guia do Terceiro Mundo. RJ: Terceiro Mundo, 1984. Ver também a posição de Aristides Royo IN Cadernos do Terceiro Mundo; n 221; p. 61; RJ: junho/julho de 2000.

33" Ministerio de Educación Pública. Guatemala, op. cit.; p.150-151

${ }^{34}$ Ibidem. p. 157.

${ }^{35}$ De acordo com o Jornal la Mesa Nacional para las Migraciones en Guatemala (Menamig)

Cadernos do Leste

Artigos Cientificos

Belo Horizonte, Edição Especial, 2000 a 2008 
Vale ressaltar que não é comum, por parte da mídia oficial, denunciar problemas dessa natureza, (que são recorrentes na fronteira entre Guatemala e México). No dia 25 de março de 2004, entretanto, El Universal anunciava:

"En su comunicado, el grupo se queja de que la militarización de la frontera entre México y el país centroamericano "hace que Guatemala se convierta en un muro de contención de los movimientos migratorios", y de hecho, provocado también un incremento de muertes de migrantes que buscan "vías alternas", para transitar por territorio mexicano". ${ }^{36}$

Jorge Morales Almada, reporter de La Opinión também publicou ${ }^{37}$, no ano de 2003, uma matéria referente às atrocidades que as autoridades mexicanas, frequentemente, cometiam contra os migrantes centro-americanos que tentavam atravessar a fronteira Guatemala-México. Na referida matéria, Almada destacou o trabalho dos organismos vinculados à defesa dos direitos humanos. De acordo com esses organismos, desaparecimentos e assassinatos correspondiam às violações mais comuns. Migrantes clandestinos da América Central são, regularmente, oprimidos na fronteira, sendo as maiores ocorrências na região sul do estado de Chiapas (cidade de Tapachula).

"Gilma Pérez, representante del Instituto de Derechos Humanos de El Salvador, indicó que el mayor número de fallecimientos que se registran de salvadoreños están sucediendo en Tapachula, Chiapas." 38

Um jornal mexicano ${ }^{39}$ noticiou a respeito de sérias violações que mulheres migrantes têm sofrido na fronteira. A matéria apresenta, inclusive, a visão de um padre brasileiro envolvido diretamente no problema:

"Con la imagen muy reciente de dos jóvenes guatemaltecas violadas y asesinadas en la primera quincena de junio en Tapachula, Chiapas, el sacerdote de nacionalidad

\footnotetext{
${ }^{36}$ El Universal, 25 de março de 2004, "Guatemaltecos exigen a México respetar derechos - Protestan en la Unión Americana por la militarización de la frontera con su país.” Do Correspondente José Carreño. Disponívelem: http://www.eluniversal.com.mx/pls/impreso/noticia.html?id_nota=109112\&tabla=Nacion ${ }^{37}$ La Opinión, 29 de setembro de 2003, "Denuncian abusos en frontera sur de México" Repórter Jorge Morales Almada. Disponível em: http://www.laopinion.com/print.html?rkey=00030928174801351953

${ }^{38}$ Op.cit.

${ }^{39}$ CIMAC, 24 de junho de 2003, "Frontera sur de México: donde todo pasa, pero todos hacen como que no pasa nada." Por Soledad Jarquín Edgar, correspondente CIMAC. Disponível em: http://www.cimacnoticias.com/noticias/03jun/s03062403.html
}

Cadernos do Leste 
brasileña, Ademar Barilli, asegura que las mujeres están totalmente vulnerables en esa frontera, donde pasa todo y todos hacen como que no pasa nada."

Barilli, atualmente coordenador da Casa do Migrante da Guatemala, defende a idéia de que as atrocidades cometidas pelas autoridades mexicanas, nessa fronteira, estão articuladas à política estadunidense de interceptação de migrantes ilegais centro-americanos. Ou seja, inibir, ou mesmo impedir a "migração clandestina" na fronteira México-Guatemala tem correspondência com acordos políticos entre os EUA e o MEX visando, assim, a diminuição do fluxo dessas pessoas na fronteira MEX-EUA e, por conseguinte, em território estadunidense.

Considerando-se essa afirmativa, a fronteira em questão assume um contorno subimperialista $^{40}$. O MEX, desta forma, acaba por reproduzir, no sul, algumas das atrocidades cometidas pelos EUA, no norte. Norte e Sul articulam-se, portanto, em direção a uma geopolítica de fronteiras - fisicamente descontínuas e distantes - comprometida com a segregação social.

"Ha muerto más gente cruzando esta frontera que la que murió tratando de cruzar el Muro de Berlín durante la Guerra Fría."41

\section{Fronteira norte}

Os astecas nem podiam imaginar que quase 1000 anos após seu auge e ascensão, o território de onde originaram estaria nas mãos de pessoas completamente diferentes do que eles eram. ${ }^{42}$

O processo de definição da atual fronteira (norte) do México evoca parte da história mexicana assim como das relações exteriores mantidas pelo país. Descendentes dos astecas e

\footnotetext{
${ }^{40} \mathrm{O}$ ingresso do México ao NAFTA tem vários significados e desdobramentos. Um dos desdobramentos pode ser verificado na ação do Estado Mexicano nas fronteiras norte e sul sinalizando, assim, uma postura contraditória: subordinação aos EUA e relativa dominação periférica junto aos países vizinhos do Istmo. Mas o sub-imperialismo mexicano manifesta-se, também, no campo econômico, a exemplo do desinteresse mexicano em ampliar os benefícios tarifários aos produtos guatemaltecos, salvadorenhos e hondurenhos.

${ }^{41}$ Monday, March 22, 2004 2:39 Un especial de National Geographic sobre uno de la inmigración de los indocumentados. Redacción.

${ }^{42}$ Destaque dos autores.
}

Cadernos do Leste

Artigos Cientificos

Belo Horizonte, Edição Especial, 2000 a 2008 
dos conquistadores espanhóis, os mexicanos foram um dos primeiros povos vítima do - até então - nascente interesse imperialista e expansionista estadunidense. Em 1853, pouco mais de 30 anos após sua independência, teriam mais de um milhão de quilômetros quadrados de seu território - aquele mesmo território outrora ocupado pelo Império Asteca - anexado (e comprado) pelos EUA por motivos diversos ${ }^{43}$.

A primeira tentativa de regionalização sofrida pelo território que hoje corresponde ao México ocorreu ainda no século XVI como resultado do modelo de administração colonial adotado pela Espanha. Este modelo consistia basicamente na divisão de seu território em Vice-reinos e Capitanias, finalizando uma gestão mais efetiva e segura (leia-se maior fiscalização) dos negócios coloniais. Assim, a porção territorial mais setentrional da colônia espanhola ficou definida como sendo o "Vice-reino da Nova Espanha"44 que compreendia todo o México atual, boa parte da América Central, além de uma grande faixa no oeste do continente norte-americano.

Anos mais tarde, sob diversas circunstâncias (internas e externas), a colônia espanhola inevitavelmente se fragmentou ainda mais ${ }^{45}$. No início do século XIX já não existiam os Vicereinados, mas sim territórios menores buscando emancipação política. O México era um deles.

Apesar de ter se tornado oficialmente independente em 1821, o México já possuía desde 1819 sua fronteira norte definida. Um acordo, o Tratado Transcontinental ${ }^{46}$, entre a

\footnotetext{
${ }^{43} \mathrm{O}$ território perdido corresponde aos atuais estados norte-americanos do Texas, Califórnia, Novo México e Arizona, além de porções dos também atuais estados de Nevada, Colorado, Oklahoma, Kansas, Wyoming e Utah.

${ }^{44} \mathrm{O}$ Vice-reino da Nova Espanha foi o primeiro a ser fundado: em 1535. Existiram ainda os Vice-reinados do Prata, de Nova Granada e do Peru.

${ }^{45}$ Não obstante as diversas tentativas de uma "união dos povos latino-americanos" (Simon Bolívar, por exemplo).

46 O Tratado Adams-Onís, ou Transcontinental como é mais conhecido, surgiu como necessidade de proteção espanhola frente às crescentes pretensões de expansão territorial estadunidense. A Espanha esperava ainda, recuperar uma região outrora em sua posse: Louisiana. É válido destacar que os EUA sempre se mostraram apreensivos quanto à possibilidade de formação de um Estado forte próximo à sua fronteira sul, o que explica a necessidade de obter porções territoriais daquela então, colônia. O conhecimento da existência de enormes riquezas minerais e, sobretudo vantagens pedológicas da região foram os maiores impulsionadores desse insistente interesse norte-americano.
}

Cadernos do Leste

Artigos Científicos

Belo Horizonte, Edição Especial, 2000 a 2008 
metrópole espanhola e os EUA garantira esse fato em 1819; e pelo menos pelas duas décadas seguintes. A linha fronteiriça definida pelo Tratado Adams-Onís seguia no sentido Califórnia, passando ao longo desse trecho, próximo ao paralelo $42^{\circ} \mathrm{N}$.

O período de cumprimento do tratado, no entanto, foi marcado por constantes pressões dos EUA, como é observado por WEBER (1992):

“(...) Estados Unidos continuó buscando la renegociación (do Tratado de 1819) mediante una serie de argumentos ingeniosos. Como secretario de Estado (dos EUA), en 1825 Henry Clay llevó el ingenio del yanqui al extremo, pues sugirió que la adquisicíon por Estados Unidos de toda la frontera norte de México lo beneficiaría, pues así su capital estaría mas al centro del país." ${ }^{4}$

Não obstante, a linha fronteiriça foi mantida e oficializada em 1832 através da ratificação de um novo tratado entre os dois países.

Se por um lado existiam pressões dos EUA, por outro os próprios governantes dos territórios ${ }^{48}$ que compunham a fronteira (norte) mexicana se sentiam insatisfeitos com as condições internas e autonomia (que não correspondiam aos seus interesses) oferecida pelo país e já vislumbravam um processo separatista. Dessa forma deve-se evitar afirmações simplistas e esclarecer que o processo de perda territorial do México foi motivado não somente por questões externas (relacionadas aos EUA), mas também por instabilidades e flagelações da política (interna) mexicana. WEBER (1992) também atenta para isso:

"Poderosas fuerzas centrífugas - regionalismo, aislamiento e influencia extranjera empezaron a alejar la frontera (norte) de la órbita mexicana en los años inmediatamente posteriores a la independência (...)" 49

Com o fim do federalismo e a adoção de um regime centralizador e mais conservador em 1835, a insatisfação já pronunciada dos "territórios da fronteira" alcançou seu ápice.

\footnotetext{
${ }^{47}$ WEBER, David J. La frontera norte de México, 1821-1846: El sudoeste norteamericano em su época mexicana. Madrid: Editorial MAFRE, 1992; p. 49-50.

${ }^{48}$ Estes eram, desde 1824 (a partir da Proclamação da República): Califórnia, Novo México e Texas. Apesar do novo regime federalista, recebiam o status de território e não de estado. Essa condição decorria da necessidade (por parte do México) de um maior controle das províncias próximas a fronteira.

${ }^{49}$ WEBER, David J. op cit. p. 409.
}

Cadernos do Leste

Artigos Cientificos

Belo Horizonte, Edição Especial, 2000 a 2008 
Nesse mesmo ano Texas rebelou-se e quis separar-se do resto do país, Califórnia tentou no ano seguinte e Novo México em 1837.

"Ante la desintegración del sistema federalista, delegados de una docena de comunidades de Texas se reunieron (...) y el 7 de noviembre de 1835 lanzaron lo que equivalió a una declaración condicional de independencia. Con base en el derecho natural, los texanos defenderían sus libertades y la Constituición de 1824.” 50

Em um confronto conhecido como "Rebelión de Texas" o Território venceu militarmente as forças centralistas do governo mexicano tornando-se oficialmente independente em 1836 sob o nome de "República do Texas". ${ }^{51}$ Por outro lado, as tentativas de separação da Califórnia e Novo México fracassaram.

O separatismo do Texas, no entanto, não veio acompanhado de um reconhecimento oficial por parte do México. O país temia que esse reconhecimento pudesse aumentar ainda mais o já significativo interesse e influência estadunidense ao longo da fronteira e num futuro (próximo) causar a perda de outras províncias do lejano norte. O que já era inevitável.

Em 1845 os EUA anexaram a República do Texas, provocando protestos e insatisfação do governo mexicano. Um ano mais tarde (em maio de 1846) como tentativa de obter as províncias da Califórnia e Novo México, o país declarou guerra ao vizinho do sul. Uma série de batalhas foi travada até fevereiro de 1848 quando o México após perder quase todas elas, cedeu e assinou o Tratado de Guadalupe Hidalgo que determinava o fim da guerra e a anexação oficial (pelos EUA) dos territórios da fronteira norte mexicana. A partir desse momento a fronteira oficial entre os dois países passou a ser delimitada pelo Rio Bravo del Norte (Rio Grande) até El Paso e a partir daí próximo aos limites norte dos atuais estados do Novo México e Arizona, o que significou para o México a perda de quase metade do seu território (contando com o Texas, já anexado anteriormente).

\footnotetext{
${ }^{50}$ WEBER, David J. op cit. p. 413.

${ }^{51}$ Alguns analistas afirmam que os EUA desempenharam um papel decisivo na vitória do então território texano sobre o México.
}

Cadernos do Leste

Artigos Cientificos

Belo Horizonte, Edição Especial, 2000 a 2008 
Apesar disso, os EUA ainda se mostravam insatisfeitos com os territórios obtidos. O desejo por uma rota de topografia plana ${ }^{52}$ em direção ao Pacífico e que passasse pela Califórnia fez com que, em 1853, o país desse início a negociações com o México visando a compra do que compreende os atuais estados do Arizona e Novo México por 10 milhões de dólares. Valor tentador para a debilitada e mal administrada economia mexicana que prontamente aceitou a proposta.

Em 1854, finalmente, a fronteira atual se estabelecia (mapa 01). Uma fronteira evidentemente peculiar e que, até a data, não consegue por si só exercer o seu principal papel de forma eficiente. Possui "lados" bastante similares (salvo no que diz respeito ao aspecto econômico), continua abrigando hispânicos por todas as partes e o espanhol ainda reina, o que, desde aqueles tempos, já prenunciava os aproximadamente 30 milhões de mexicanos que viveriam anos depois nos EUA.

"No hay duda de que el Lejano Norte mexicano iba cayendo rapidamente bajo la influencia norte americana, pero también es igualmente claro que las instituiciones y la sociedad de la región siguieron siendo esencialmente mexicanas mientras formaron parte de esa joven y turbulenta nación. Los muy complejos acontecimientos ocurridos en la frontera norte de Mexico sólo se pueden entender cabalmente cuando se estudia a la región desde puntos de vista mexicanos y norteamericanos." 53

Mapa 1: Expansionismo estadunidense sobre o território mexicano

\footnotetext{
${ }^{52}$ Uma rota desse tipo somente seria possível (ainda que de forma precária) a sul do Rio Gila, há apenas alguns quilômetros (aproximadamente 200) da atual fronteira. Pouco mais ao norte, as protuberâncias das Montanhas Rochosas impediam a realização de tal desejo.

${ }^{53}$ WEBER, David J. op cit. p. 474.
}

Cadernos do Leste

Artigos Cientificos

Belo Horizonte, Edição Especial, 2000 a 2008 


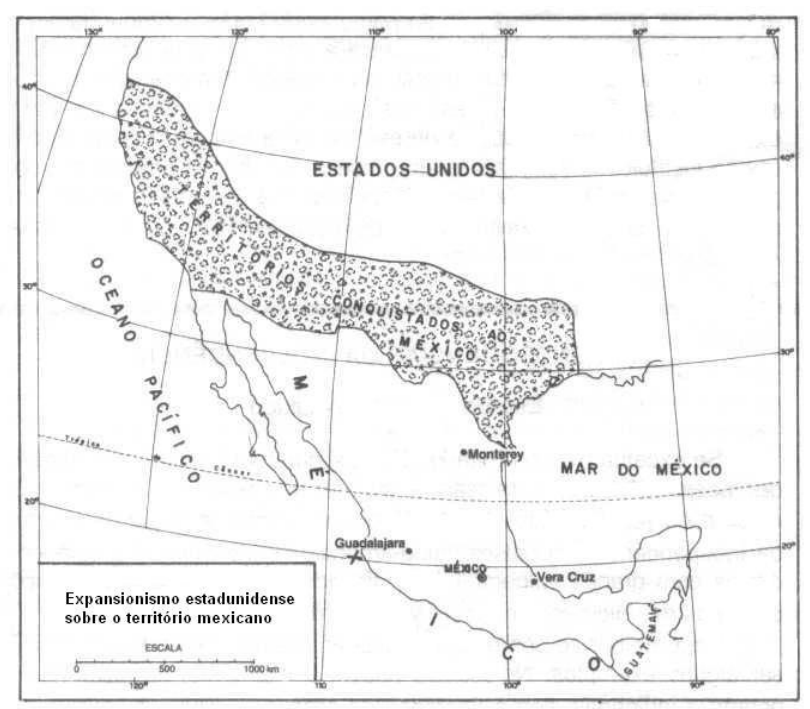

Fonte: ANDRADE, M. C. 1989.

\section{4- O MURO ESTADUNIDENSE: UM LONGO PERCURSO NA DIREÇÃO DO DESENCONTRO}

“O muro de Berlim ainda está lá, só que invisível." 54

Casos típicos de "fronteiras vivas" manifestam-se, visivelmente, neste início de século. Israel começou, recentemente, a construção de um muro para segregar ainda mais os palestinos $^{55}$. Dividindo as Coréias, na altura do paralelo 38, persiste um muro (cerca de arame farpado com $250 \mathrm{~km}$ de extensão) que, em parte, representa um considerável resquício da Guerra Fria $^{56}$. No Saara Ocidental, um muro fortificado, de $1.800 \mathrm{~km}$ de extensão, separa o

54 Wenders citado por Moura in MOURA, R. Fronteiras invisíveis: o território e seus limites. IN Território/LAGET, UFRJ - ano V, n 9 - RJ: UFRJ, p.95, 2000.

${ }^{55}$ Cerca de 180 dos $730 \mathrm{~km}$ planejados já foram construídos. Por esse motivo, povoados inteiros da Cisjordânia ficaram isolados de supermercados, hospitais e escolas. Mais de mil hectares de terras privadas foram confiscadas e 102 mil árvores arrancadas. Ver Jornal Estado de Minas de 24 de fevereiro de 2004; p. 11. Em julho de 2004, a Corte Internacional de Justiça (CIJ), reunida em Haia, declarou ilegal o muro construído por Israel.

${ }^{56}$ Ainda hoje, os E. U. A. vigiam a fronteira sul com cerca de 40.000 militares.

Cadernos do Leste

Artigos Científicos

Belo Horizonte, Edição Especial, 2000 a 2008 
território dominado pelos marroquinos da região leste ocupada pela organização separatista Polisário. $^{57}$

$\mathrm{Na}$ fronteira do México com os EUA, um muro muito particular também cumpre um papel geopolítico importante. Cabe aqui, pelo menos, caracterizar sua materialidade e, também, pensar sobre os seus significados para as populações mais diretamente envolvidas.

\section{Uma caracterização geográfica do muro estadunidense}

Durante todo o século passado e sobretudo a partir de meados dos anos oitenta o poder público estadunidense, preocupado com a intensificação dos fluxos migratórios de hispânicos ilegais em direção ao país, buscou medidas de maior eficiência possível para alteração dessa situação. A possibilidade de construção de um muro fronteiriço entre os EUA e o seu vizinho México - como reforço à sempre existente patrulha policial - mostrou-se mais concreta por volta de 1990. Porém., foi a partir de um "pacote" de medidas governamentais (regulamentado em meados dos anos 90) que a construção do muro ficou determinada e logo assim colocada em prática. (figura 01)

Fundamentada na necessidade de conter os crescentes fluxos ilegais de migrantes latinos, especialmente mexicanos, em direção ao país, a política dos anos 90 postulava que o SIN (Serviço de Imigração e Naturalização) ficaria encarregado de executar o plano multimilionário ${ }^{58}$ de construção do muro para a contenção dos indocumentados. Devido à grande extensão ${ }^{59}$ territorial da fronteira entre os dois países foram estabelecidos, inicialmente, pontos prioritários para a construção do muro. Por conseguinte, as áreas de

${ }^{57}$ Este muro teve sua construção iniciada nos anos 80, por decisão do governo marroquino. Corta todo território do Saara Ocidental seguindo (grosso modo) a direção NE-SO. Em função do conflito entre Marrocos e os separatistas (população local - saarauís) dezenas de milhares de pessoas foram mortas e, em 2000, o número de refugiados superava 190.000 (a maior parte desses dirigindo-se para a Argélia).

${ }^{58}$ Somente em 2000, os EUA gastaram cerca de US\$ 2 bilhões em sua fronteira com o MEX, objetivando reforçar o contigente policial e as tecnologias empregadas. Ver CARDOSO, A. Migrações internacionais os blocos regionais e a mobilidade mundial de mão-de-obra. IN: São Paulo em Perspectiva, ano II, $\mathrm{n}^{\circ} 16$, p.112-124, 2004.

${ }_{59}$ A fronteira comum entre os dois países possui, aproximadamente, 3.140 quilômetros de extensão. Destes 3.140, 2.018 quilômetros acompanham o leito do Rio Grande (porção oriental da fronteira). Os outros 1.123 atravessam uma região desértica de clima árido e vegetação xerófila.

Cadernos do Leste

Artigos Cientificos

Belo Horizonte, Edição Especial, 2000 a 2008 
fronteira que receberam maior atenção foram as de maior concentração populacional e de maior fluxo migratório, como os centros urbanos de San Ysidro ${ }^{60}$, Tecate e Campo Andrade, na Califórnia; San Luis, Nogales, Naco e Douglas, no Arizona e El Paso e Brownsville, no Texas (mapa 02).

Figura 1: um pequeno trecho do muro na porção ocidental, México e EUA - 1997.

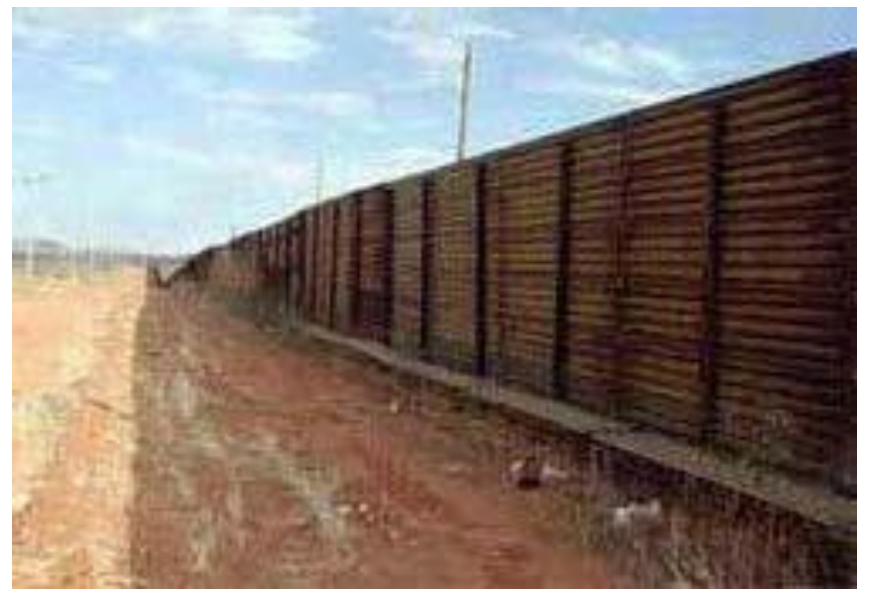

Fonte: http://resistir.info/mexico/muro_mexico.html - 18/04/2004

A porção mais ocidental da divisa entre os dois países, onde estão as cidades de San Diego (EUA) e Tijuana (MX), foi considerada pelo SIN como um dos pontos mais críticos da fronteira o que exigiria, portanto, uma atenção especial. Nessa região, a construção do muro fronteiriço se deu de forma rápida e urgente. Este surge logo a 150 metros mar adentro (Oceano Pacífico), atravessa as areias da praia californiana, corta as duas cidades e segue por uma série de colinas (figuras 02 e 03). As vezes, chega à ultrapassar 8 metros de altura, sendo composto por barras verticais de cimento ou aço. Em seguida, ainda em um relevo caracterizado por colinas, o muro se transforma em uma cerca de ferro e arame farpado um pouco mais baixa, que avança ininterruptamente por 24 quilômetros, a leste. Segundo

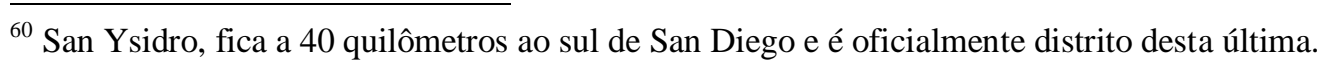

Cadernos do Leste

Artigos Científicos

Belo Horizonte, Edição Especial, 2000 a 2008 
Azevedo (1998), nesta porção territorial da fronteira, o muro está sendo constantemente reforçado. $^{61}$

Seguindo a linha da fronteira (na direção oeste-leste), o muro desaparece por quase 200 quilômetros em uma região desértica e inóspita que é demarcada, simplesmente, através de marcos de pedra instalados pelos norte-americanos. No entanto, a ausência de um muro nessa área não significa facilidade de travessia. Há um forte e constante sistema de patrulhamento (as border patrols ${ }^{62}$ ) que vasculha incansavelmente a fronteira em busca de migrantes ilegais, conforme mencionado por Azevedo (1998); (figura 04).

Mapa 2: Áreas de maior atenção do SIN na fronteira entre México e EUA.

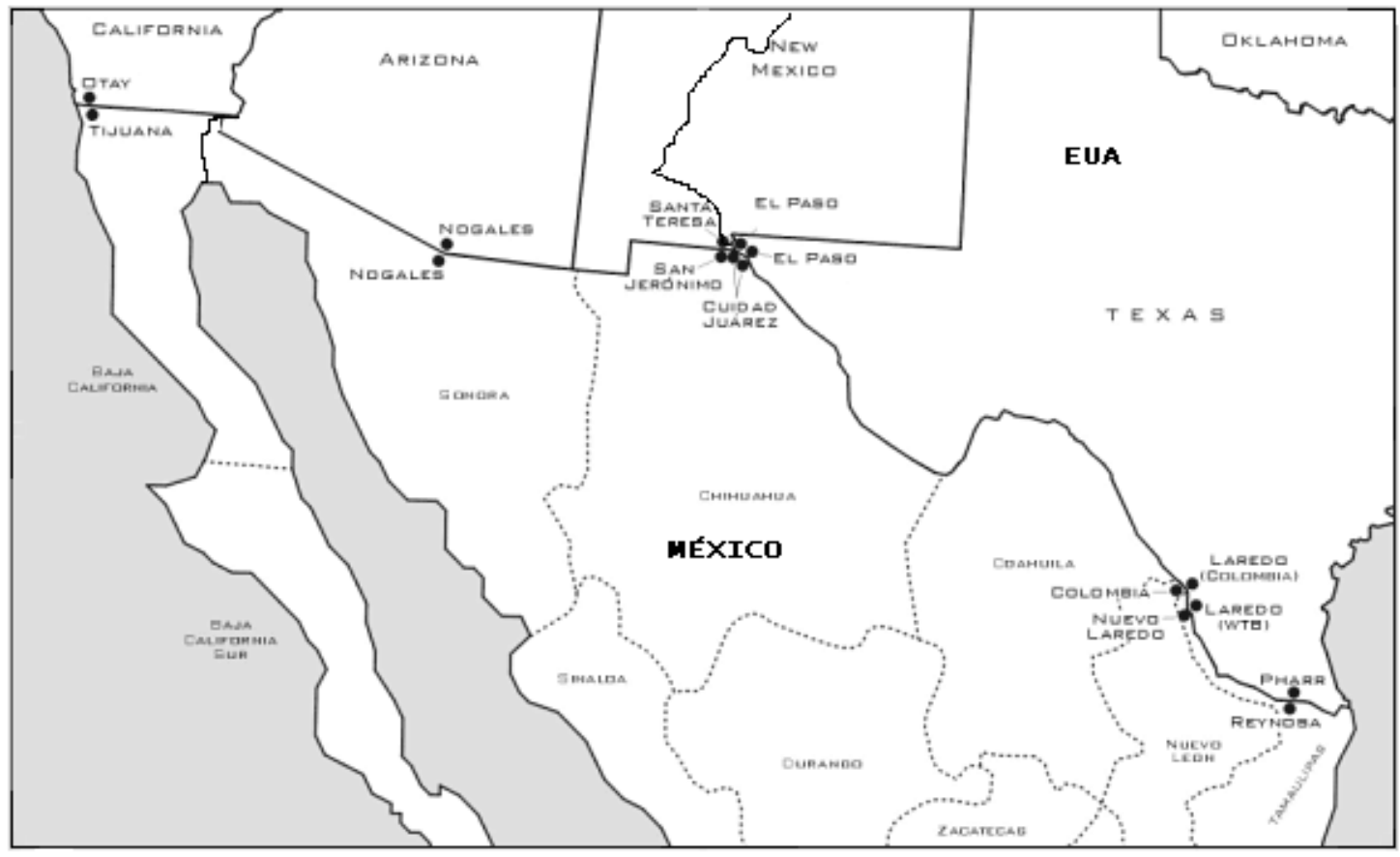

${ }^{61}$ Os dados e estatísticas referentes ao muro e sua extensão, citados ao longo dessa parte do artigo, foram retirados de "Revista Manifesto (edição n ${ }^{\circ}$ 0), O muro americano, São Paulo, Instituto Gutenberg, 1998". A revista traz nessa edição uma única reportagem, de Carlos de Azevedo, que percorreu em 1997 a extensa fronteira entre México e EUA.

${ }^{62}$ A border patrol é a "polícia de fronteira". Criada pelo governo estadunidense em 1924, atualmente é composta por mais de 10.000 mil agentes.

Cadernos do Leste

Artigos Cientificos

Belo Horizonte, Edição Especial, 2000 a 2008 
Elaborado por FRANCA, R. R. baseado em http:// www.nmsu.edu

Figura 2: costa oeste da América do Norte (fronteira entre Tijuana e San Ysidro); materialização da fronteira mar adentro.

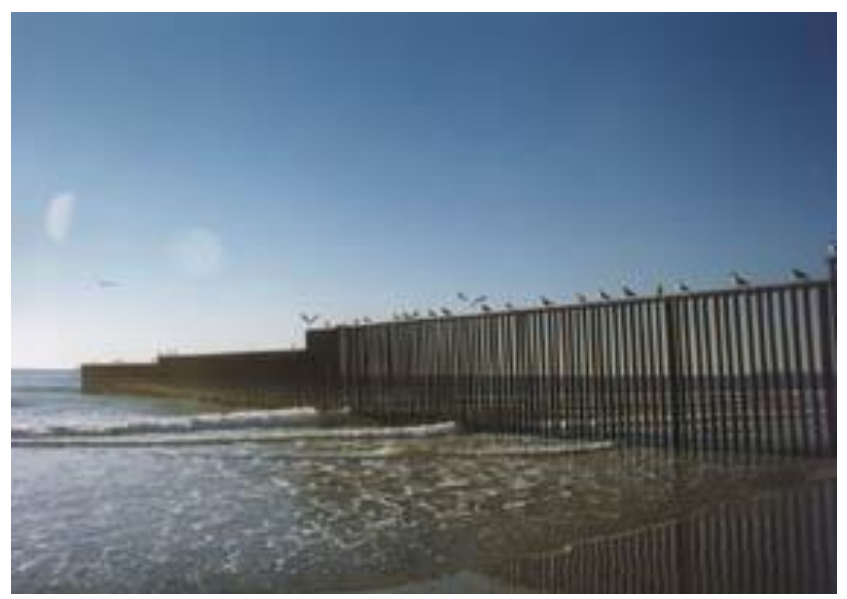

Fonte: http://resistir.info/mexico/muro_mexico.html - 18/04/2004

Figura 3: o espaço naturalmente hostil (deserto montanhoso) pelo qual o muro se estende denota sua fragilidade. Não importa o lado que está, o migrante ainda terá muito o que suportar até chegar em seu destino final. Região de Tijuana, Califórnia. 


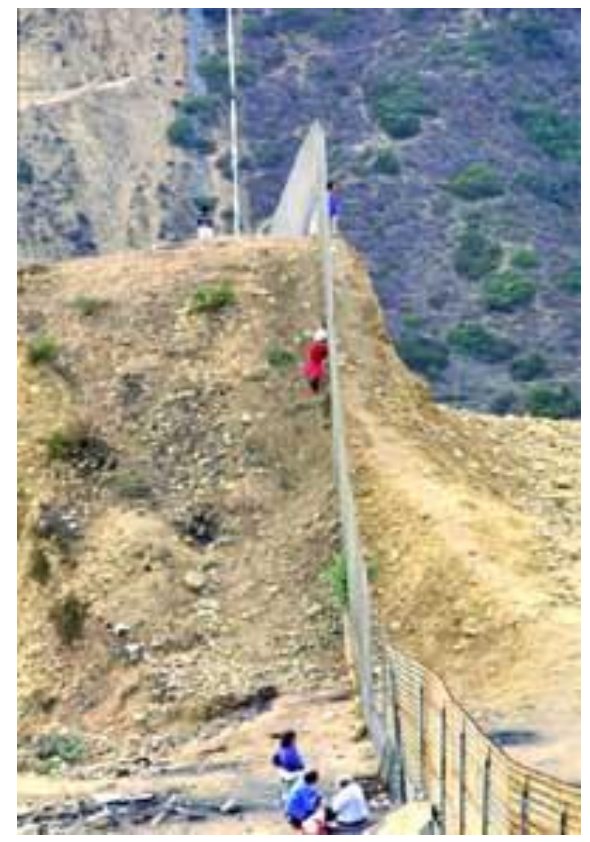

Fonte: http://resistir.info/mexico/muro_mexico.html - 18/04/2004

Figura 4: o carro da "patrulha de fronteira" e seus agentes em reunião. Estratégias

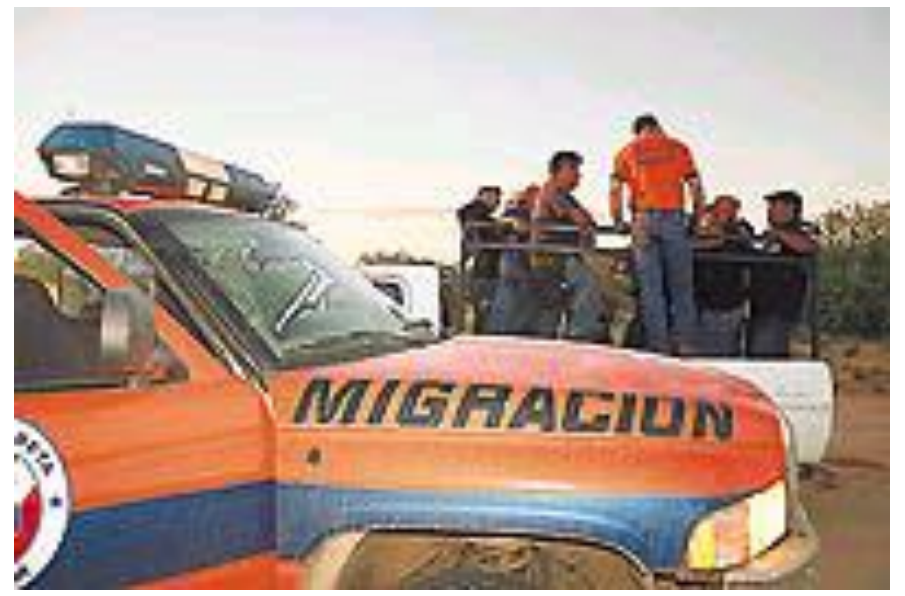

para capturar migrantes ilegais?

Fonte: http://resistir.info/mexico/muro_mexico.html - 18/04/2004 
O muro de ferro só reaparece nas proximidades de Caléxico (EUA) e Mexicali (MX), região ainda desértica e montanhosa. Nessa porção da fronteira, as barreiras de concreto e metal constituem apenas pequenos obstáculos para aqueles que pretendem ultrapassá-la. Os maiores empecilhos são, na verdade, as condições climáticas e a vigilância dos agentes da polícia de fronteira.

O sudoeste da América do Norte se destaca pela presença de uma das mais extensas áreas desérticas do mundo. Desertos como o do Colorado e o Gila - regionalmente também conhecido como "de Sonora" ou ainda "do Arizona" - se articulam formando o grande deserto Mojave. Localizado majoritariamente entre o Trópico de Câncer e o paralelo $35^{\circ}$, Mojave é caracterizado como um deserto costeiro do tipo temperado, isto é, apresenta significativa amplitude térmica diária, contudo, visivelmente inferior àquelas encontradas em desertos quentes como o do Saara, na África. ${ }^{63}$ Este fato pode ser atribuído, principalmente, à influência direta da maritimidade: sua grande proximidade ao Oceano Pacífico e a consequente ação direta de correntes de ar dessa natureza certamente contribuem para uma amenização da característica em questão.

Figura 5 - Localização do Deserto de Mojave e das estações meteorológicas de Mesa e de Tucson (consultadas)

${ }^{63}$ Segundo dados de estações meteorológicas de Tucson e Mesa (Arizona, EUA), durante todo o ano a amplitude térmica diária fica sempre em torno de $15^{\circ} \mathrm{C}$. No deserto do Saara, por exemplo, esse valor pode chegar até $50^{\circ} \mathrm{C}$.

Cadernos do Leste

Artigos Cientificos

Belo Horizonte, Edição Especial, 2000 a 2008 


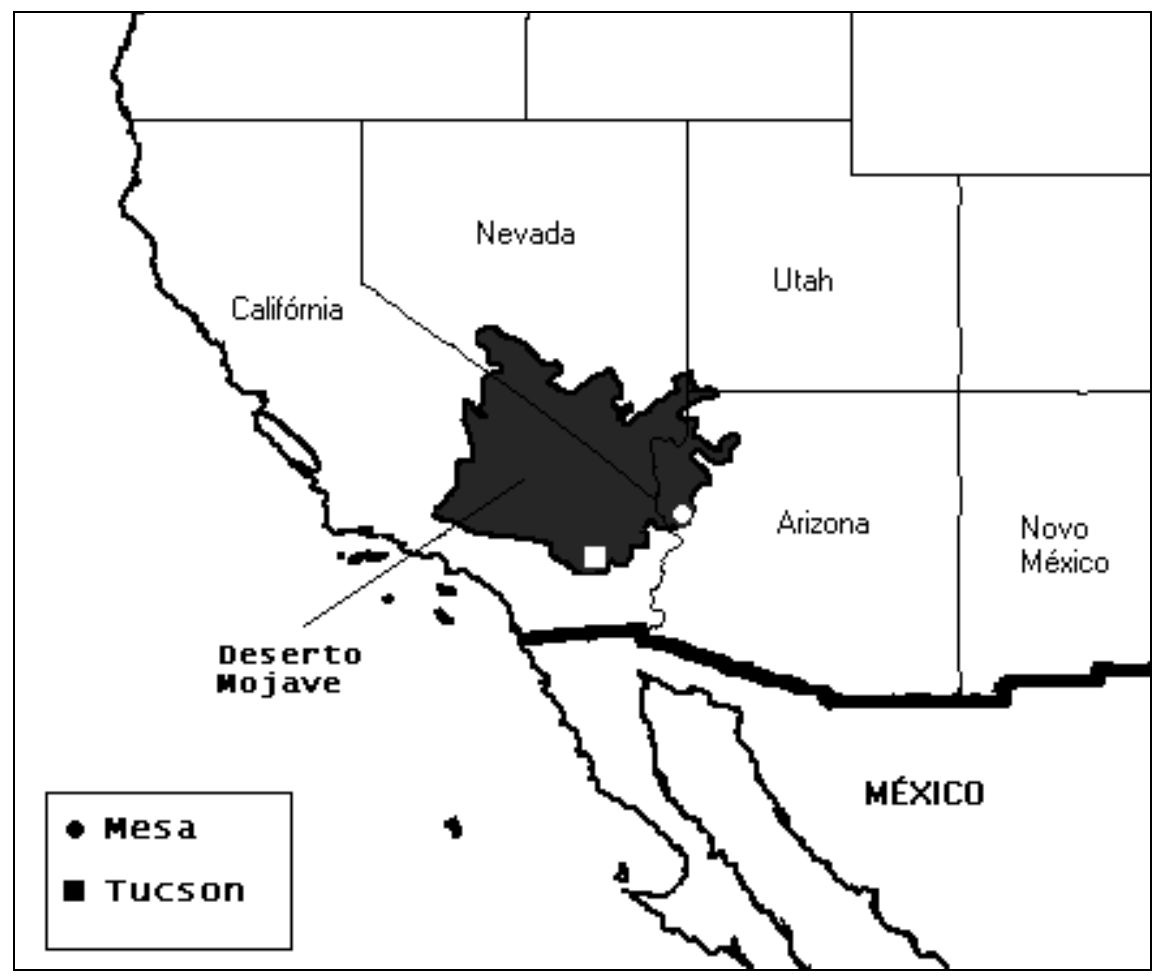

Fonte: elaborado por FRANCA, R. R. baseado na Enciclopédia Encarta 99 (CD $\mathrm{ROM})$

Apesar disso, Mojave apresenta comportamento comum aos desertos quentes quanto à baixa pluviosidade anual (inferior à $250 \mathrm{~mm}$ ), sendo sua distribuição bastante irregular durante os doze meses. O gráfico a seguir, executado a partir de dados climatológicos de uma estação em Tucson (Arizona, EUA) ${ }^{64}$, a 445 metros de altitude, sintetiza essas informações:

${ }^{64}$ Os dados foram obtidos através do site: www.worldclimate.com no dia 18/02/05. São de natureza climatológica (caráter compilatório) o que fornece segurança em sua utilização nas análises aqui encorajadas. 
Gráfico 1 - Temperatura (1961-1990) e Precipitação (1931-1995); Tucson (445m de altitude).

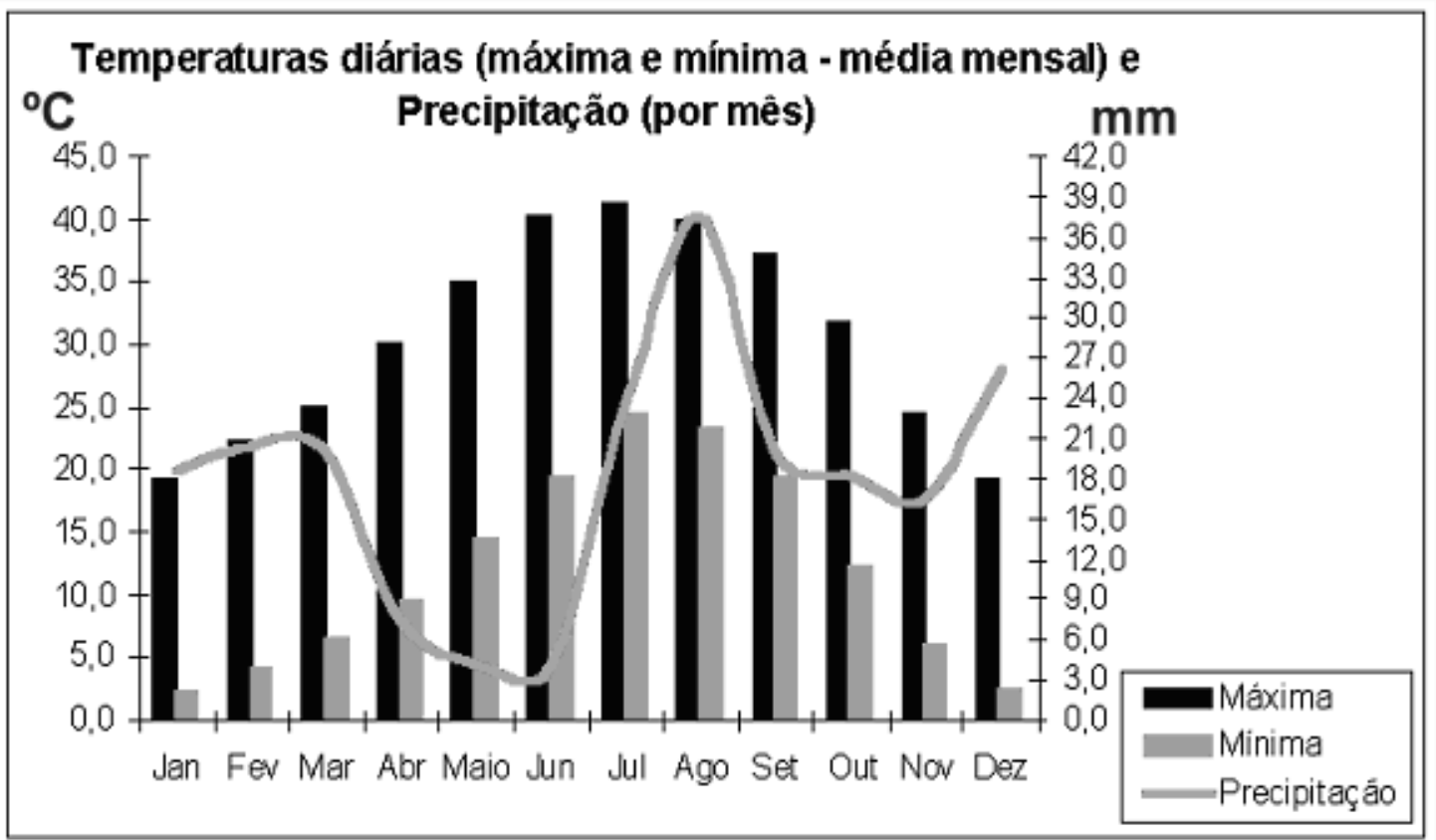

Fonte: elaborado por FRANCA, R. $\mathrm{R}$ a partir de dados disponíveis em www.worldclimate.com

O gráfico atesta para as altas temperaturas máximas encontradas nos meses de junho, julho e agosto (próximas aos $40^{\circ} \mathrm{C}$ ), época que corresponde ao verão boreal. Já nos meses de dezembro, janeiro e fevereiro (inverno) observam-se temperaturas mínimas destacadamente baixas. A diferença entre as barras correspondentes às médias das temperaturas máximas diárias durante um mês e a média das temperaturas mínimas diárias representa a amplitude média diária durante o mesmo mês. Percebe-se que este valor é sempre alto, durante todo o ano, e sobretudo nos meses de abril, maio e junho. Concomitantemente esses também são os meses quando há menos precipitação. Nesse sentido, essa época do ano, junto com o verão, pode ser considerada uma das mais arriscadas para tentativa de travessia da fronteira.

Considerando apenas os impedimentos naturais, sugerimos o quadro a seguir, que ordena as estações do ano em graus de risco de morte para o migrante: 
Quadro 1: Riscos de vida para o migrante segundo as estações do ano

\begin{tabular}{|l|l|l|l|}
\hline \multicolumn{1}{|c|}{ Possibilidade } & \multicolumn{1}{|c|}{ Risco } & \multicolumn{1}{c|}{ Morte } \\
\cline { 1 - 4 } & Migrar no verão & Altas temperaturas máximas & $\begin{array}{l}\text { Insolação, } \\
\text { desidratação; }\end{array}$ \\
\hline Migrar na primavera & Precipitações quase inexistentes & $\begin{array}{l}\text { Desidratação } \\
\text { aguda }\end{array}$ \\
\hline Migrar no inverno & Baixas temperaturas mínimas & $\begin{array}{l}\text { Hipotermia, } \\
\text { desidratação }\end{array}$ \\
\hline Migrar no outono & $\begin{array}{l}\text { Época de menores riscos: } \\
\text { temperaturas menos rigorosas, } \\
\text { maiores precipitações. Entretanto, } \\
\text { cheia dos rios. }\end{array}$ & $\begin{array}{l}\text { Afogamento, } \\
\text { desidratação }\end{array}$ \\
\hline
\end{tabular}

Fonte: elaborado por FRANCA, R. R.

Os dados sobre mortes na fronteira, no ano de 1999, confirmam o quadro anterior:

Tabela 1: Número de mortes na Fronteira, por mês e causa - 1999.

\begin{tabular}{|l|r|r|r|r|r|r|r|r|r|r|r|r|r|}
\hline Causas & Jan & Fev & Mar & Abr Mai Jun Jul & Ago & Set & Out & v & Dez & \\
\hline Hipotermia & 17 & 12 & $\mathbf{1 2}$ & $\mathbf{1 5}$ & $\mathbf{2}$ & - & - & - & - & 4 & 3 & 67 & 132 \\
\hline Insolação & 3 & - & 2 & $\mathbf{5}$ & $\mathbf{8}$ & $\mathbf{1 0}$ & $\mathbf{2 8}$ & $\mathbf{4 0}$ & 12 & 5 & 2 & 118 & 233 \\
\hline Afogamento & 7 & 4 & $\mathbf{1 8}$ & $\mathbf{2 1}$ & $\mathbf{1 1}$ & $\mathbf{1 4}$ & $\mathbf{1 0}$ & $\mathbf{2 0}$ & 7 & 7 & 3 & 128 & 250 \\
\hline Total & 27 & 16 & $\mathbf{3 2}$ & $\mathbf{4 1}$ & $\mathbf{2 1}$ & $\mathbf{2 4}$ & $\mathbf{3 8}$ & $\mathbf{6 0}$ & 19 & 16 & 8 & 313 & 615 \\
\hline
\end{tabular}

Fonte: Claudia Smith, de Califórnia Rural Legal Assistence, com dados do Consulado Mexicano em San Diego, Califórnia. www.tij.uia.mx - 05/10/2004. 
Em negrito, destacam-se os meses correspondentes ao verão e primavera. Como pode ser verificado, este é o período do ano de maior número de mortes em duas das três causas contabilizadas.

Levando em conta os dados referentes a dezembro, cabe levantar hipóteses para justificar o elevado e discrepante número de mortes nesse mês (inverno):

- Provavelmente há um incremento do fluxo de migrantes nesse mês, o que resulta também em aumento no número de mortes. Esta possível situação pode ser motivada por:

> grande necessidade de iniciar "vida nova" no país de destino sistematicamente no início do ano;

uma forte associação de deserto a calor extremo; logo, uma busca por parte do migrante pelo seu extremo oposto: o frio, que "naturalmente é encontrado no inverno" (meses de dezembro a março). Essa associação simplificada sinaliza falta de conhecimento sobre as adversidades próprias do deserto.

$>$ coyotes, em uma atitude estratégico-maliciosa, aproveitando-se desse desconhecimento, omitiriam os perigos do inverno. Supõe-se que com um provável fracasso de travessia de alguns grupos, os coyotes seriam beneficiados através de uma (re)contratação de seus serviços. Poder-se-ia dizer que essa suposição não se fundamenta, uma vez que constituiria uma autopublicidade (do tipo "boca-a-boca") negativa contra os próprios coyotes e contra a travessia no inverno. Entretanto, em guerra publicitária o "boca-a-boca" é muito menos eficiente do que os rios de tinta e imagens geradas diariamente pelo grandes meios de comunicação, que insistem enfaticamente nos perigos do verão.

Cadernos do Leste 
É importante salientar, entretanto, que devido à grande diversidade de condições ambientais diretamente decisivas para o clima, como o relevo (altitude ${ }^{65}$, o comportamento climático observado acima sofre importantes variações em curtas distâncias. Ainda em Tucson, agora em uma estação localizada em uma altitude superior (1374 m) a da anterior, o clima é sensivelmente mais moderado: as médias das máximas diárias durante um mês são menores, assim como das mínimas diárias. O valor anual de precipitação é destacadamente superior: $582.4 \mathrm{~mm}$.

Tabela 2: Temperatura (1961-1990) e Precipitação (1950-1995) -

Tucson $(1374 \mathrm{~m})$

\begin{tabular}{|c|c|c|c|c|c|c|c|c|c|c|c|c|c|}
\hline Meses & Jan & Fev & Mar & Abr & Mai & Jun & Jul & Ago & Set & Out & Nov & Dez & Ano \\
\hline Máxima $\left({ }^{\circ} \mathrm{C}\right)$ & 14.0 & 16.1 & 18.2 & 23.0 & 28.0 & 33.4 & 33.7 & 32.0 & 29.8 & 25.0 & 18.6 & 14.2 & 23.8 \\
\hline Mínima $\left({ }^{\circ} \mathrm{C}\right)$ & 1.6 & 2.7 & 4.3 & 7.6 & 12.0 & 17.3 & 19.2 & 18.5 & 16.0 & 10.8 & 5.3 & 2.0 & 9.8 \\
\hline Amplitude & 12.4 & 13.4 & 13.9 & 15.4 & 16.0 & 16.1 & 14.5 & 13.5 & 13.8 & 14.2 & 13.3 & 12.2 & 14.0 \\
\hline recipitação (mm) & 53.5 & 51.4 & 63.2 & 22.8 & 11.9 & 9.3 & 78.1 & 96.5 & 48.4 & 44.4 & 40.5 & 61.6 & $\mathbf{5 8 2 . 4}$ \\
\hline
\end{tabular}

Fonte: www.worldclimate.com no dia 18/02/05.

Dados como estes somente confirmam o grande mosaico de situações para as quais o migrante deve estar preparado ao iniciar sua empreitada: frio, calor, falta de água, animais ameaçadores, aclives acentuados, vazios demográficos, enfim, situações muito adversas.

No entanto, todos esses entraves parecem não intimidar os migrantes que sonham com uma vida melhor nos EUA. O número de pessoas que tentaram atravessar essa região da fronteira aumentou, assim como o de mortes, que subiu de 10 por ano (média nos anos de 1993 a 1997) para 33 somente nos oito primeiros meses de 1997. Para a totalidade territorial da fronteira, dados do governo mexicano indicam que (apenas) no ano de 2000, morreram

${ }^{65}$ Relevo extremamente irregular e montanhoso.

Cadernos do Leste

Artigos Cientificos

Belo Horizonte, Edição Especial, 2000 a 2008 
499 mexicanos $^{66}$. Estas mortes, em sua maioria, se deram através de afogamento, desidratação ou por algum outro tipo de acidente ou agressão.

Prosseguindo na direção oeste-leste, constata-se que nos próximos 38 quilômetros a linha de fronteira atravessa o Rio Colorado e se inclina ligeiramente para sudeste. Nota-se, também, que a partir daí, a vegetação desértica se destaca ainda mais, estendendo-se ao longo do Deserto do Arizona (ou de Sonora, como conhecido no México). Essas características fitogeográficas permanecem por cerca de 450 quilômetros até as proximidades de Nogales, localidade priorizada pelo SIN, desde o início dos anos de 1990. Nesses últimos 450 quilômetros, até a cidade de Nogales, o muro é simplesmente um alto alambrado. A partir de Nogoles, porém, ele é bastante reforçado através de chapas de ferro, que são fortemente fixadas no chão por meio de bases de cimento. Além disso, um amplo e variado artefato tecnológico, como sensores infravermelhos, câmeras estratégicas e iluminação moderna garante o rastreio de pessoas para a polícia fronteiriça. Azevedo (1998) descreve a região da seguinte forma:

“Cinqüenta quilômetros antes de Nogales, já dou com uma daquelas camionetes reforçadas da border patrol. Primeiro sinal de que a imigração ilegal é forte nesta área. (...) Passo pela alfândega, estou no México, fácil assim. Nogales, Sonora, é uma cidade pobre, com um comércio de recuerdos para turistas ianques. E muita gente pelas ruas - desempregados, biscateiros, camelôs. Aqui o mesmo tipo de muro de chapas de metal reaparece reforçado, agressivamente equipado com câmeras de TV e sensores, separando as duas cidades de ponta a ponta. É todo cimentado por baixo, não dá para cavar como em Tijuana." ${ }^{67}$

De Nogales até a cidade mais próxima (Tombstone) são 80 quilômetros. Douglas, no extremo sudeste do Arizona (EUA) e Água Prieta, em Sonora (MEX) estão 150 quilômetros depois. Nesse trecho da fronteira, o muro ainda está em construção, somente seus pilares estão instalados. Devido a esta "interrupção", o patrulhamento é intenso. Essas características se reproduzem ao longo de toda a região da fronteira que abrange o estado do Novo México

66 "México-EEUU: Este muro sí”: Por: Diego Cevallos/IPS. Publicado em 29 de outubro de 2003. IN: Asamblea Popular Revolucionaria http://www.aporrea.org (artículo).

${ }^{67}$ AZEVEDO, C. op cit.

Cadernos do Leste

Artigos Científicos

Belo Horizonte, Edição Especial, 2000 a 2008 
(EUA) e Chihuahua (MEX), até as cidades de El Paso (EUA) e Ciudad Juárez (MEX) o que representa 350 quilômetros de distância entre Douglas e estas duas cidades.

A partir desse local - divisa entre El Paso e Ciudad Juarez - a fronteira passa a ser demarcada pelo Rio Grande (ou Rio Bravo del Norte, para os mexicanos). Com nascente nos montes de San Juan, sudoeste do estado do Colorado, o rio coincide com a fronteira MéxicoEUA até o seu extremo mais oriental, quando desemboca no Golfo do México. Novamente, torna-se pertinente citar as observações de Azevedo (1998):

"Canalizado, o rio corre entre rampas de cimento separando as duas cidades (...) o Rio Grande (Rio Bravo del Norte, para os mexicanos) alcança a fronteira. Suas águas escuras já chegam poluídas do interior dos Estados Unidos. É uma torrente estreita, não excede aos 60 metros em largura, mas corre veloz separando El Paso de Ciudad Juárez." 68

A existência de um rio como divisor e demarcador natural da fronteira (figura 06) não inibe completamente a construção do muro; este ainda comparece nos locais considerados relevantes para o SIN - geralmente, as áreas que apresentam maior grau de urbanização. ${ }^{69}$ Se antes o muro era alto, moderno e extremamente fortificado, agora aparece como pequenos alambrados ou sob a forma de marcos de pedra, às vezes, não podendo ser caracterizado propriamente como um muro. Cabe ressaltar que essa condição "variada" e fragmentada do muro não se aplica ao papel de vigilância da polícia fronteiriça, que permanece ativa ao redor de toda a fronteira apresentando-se, nesses locais, ainda mais intensificada.

${ }^{68}$ Ibidem.

69 "Cidades de fronteira" maiores e de importância nacional não são mais encontradas até o final da fronteira. Entretanto, a 1.500 quilômetros depois de El Paso e Ciudad Juarez, destacam-se Laredo, no Texas (EUA) e Nuevo Laredo, em Nuevo Leon (MEX), por serem econômica e demograficamente um pouco mais significativas. Nesse ponto, o muro está presente assim como o policiamento, mais reforçado.

Cadernos do Leste

Artigos Cientificos

Belo Horizonte, Edição Especial, 2000 a 2008 
Figura 6: o rio Grande como "fronteira natural" entre os dois países; trecho nas proximidades de Ciudad Juarez, Chihuahua e El Paso, Texas.

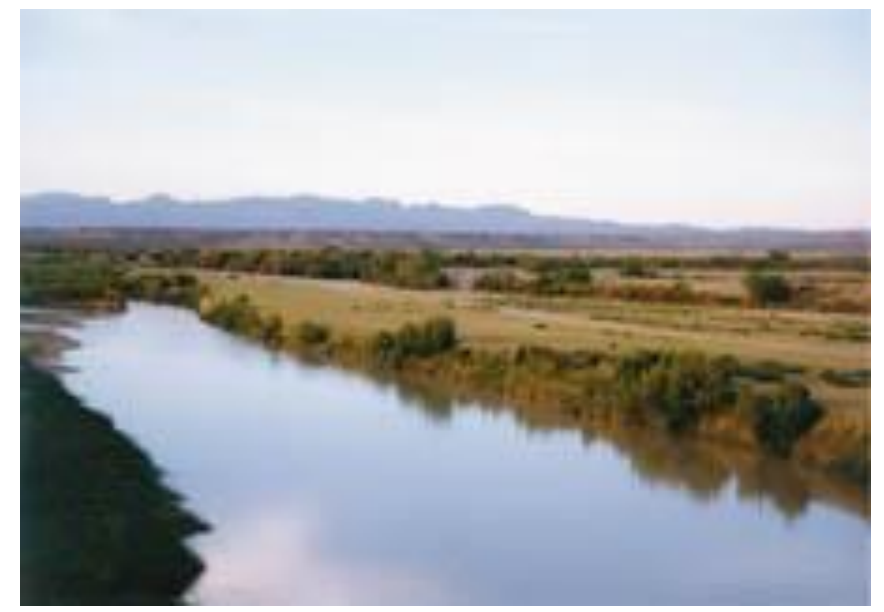

Fonte: http://resistir.info/mexico/muro_mexico.html - 18/04/2004

Nos últimos 350 quilômetros da fronteira (sentido oeste-leste), mantém-se a estratégia do muro emergir prioritariamente em áreas urbanas. Entre as cidades de Brownsville (Texas) e Matamoros, no entanto, ele não está presente, conforme aponta Azevedo (1998):

"Ao chegar em Brownsville, eu iria enfrentar uma dificuldade: onde é a fronteira? Claro, há uma alfândega, uma ponte internacional sobre um mirrado braço do Rio Grande. No mais, a costumeira linha divisória formada pelo rio se dilui. Represadas nas terras baixas, suas águas entram num estuário e se esparramam por restingas e baías e se misturam com as águas do mar, em Boca Chica, em Brownsville, em Port Isabel”. (ver figura 07). 
"Penso que essa ambiguidade geográfica coincide com outra, a ambiguidade nacional e racial que se observa aqui. Não é bem um confronto, mas uma tentativa de ser ao mesmo tempo as duas coisas. Esbarra no preconceito norte-americano e se enche de ressentimento. Recusa o confronto, mas infiltra-se como água. E se amplia, não sendo apenas o encontro abrasivo da cultura norte-americana com a mexicana, mas com a cultura latina (há milhões de cubanos, salvadorenhos, dominicanos, portoriquenhos, guatemaltecos, colombianos, venezuelanos e brasileiros nos Estados Unidos)." 70

Para Azevedo (1998), o ambicioso projeto dos anos de 1990 que propunha, entre outras coisas, a construção de uma barreira fronteiriça também aspirava, de certa forma, o que encontra-se atualmente nos limites destes distintos países. Mesmo a descontinuidade do "Muro de la Tortilla"71 ao longo da fronteira não foi capaz de impedir o sucesso do plano, que alcançou e vem alcançando seus objetivos; isso porque seu êxito não se deu propriamente pelo muro alto e tecnologicamente seguro que foi construído, mas sobretudo pelas diversas patrulhas humanas que o vigiam constantemente. Neste caso a muralha é apenas simbólica.

Figura 7: foz do Rio Grande no Golfo do México (extremo leste da fronteira).

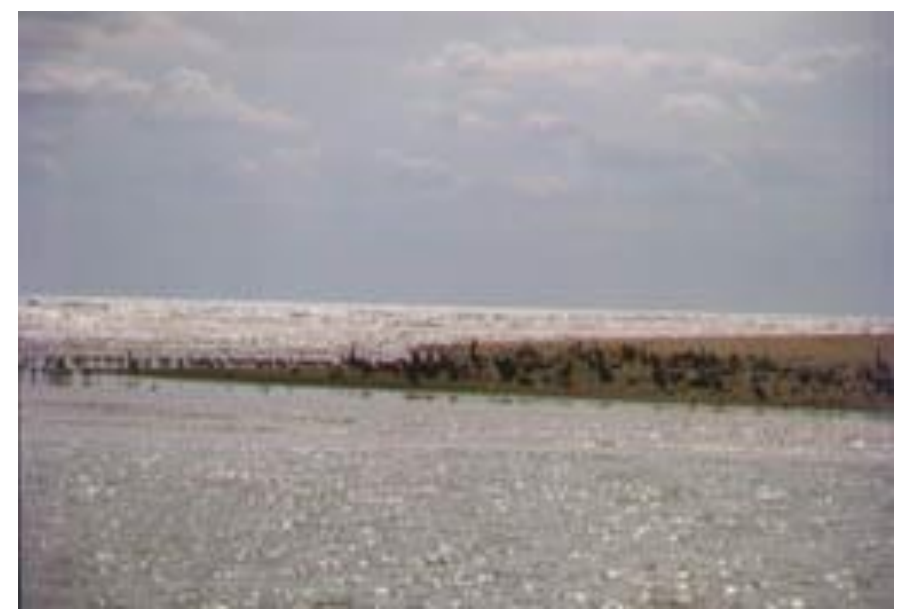

Fonte: http://resistir.info/mexico/muro_mexico.html - 18/04/2004.

\footnotetext{
${ }^{70}$ AZEVEDO, C. op cit . p.

71 "Muro de la Tortilla" é um dos nomes que o muro recebe pelos mexicanos. Faz alusão a uma das comidas típicas do país.
}

Cadernos do Leste

Artigos Cientificos

Belo Horizonte, Edição Especial, 2000 a 2008 
Para os mexicanos que vivem na fronteira, entretanto, o muro é muito mais do que isso. É o local onde suas vontades e esperanças são barradas, enquanto sentimentos como, tristeza, revolta, decepção e injustiça vêm a tona. Além disso é o momento em que se deparam com uma sensação de segregação.

Azevedo (1998), logo no início de sua viagem pela fronteira destaca o seu caráter relativamente unilateral:

“(...) para entrar no México, há liberdade total, exceto por um policial postado ao lado de uma placa onde se diz que você deve declarar mercadorias que vá levando." 72

A questão da migração é realmente grave e deve ser cuidadosamente analisada. As estatísticas mais recentes do Censo de 2001 afirmam haver mais de 35 milhões de latinos (legais e ilegais) nos EUA, sendo que 25 milhões são mexicanos (por nascimento ou ascendência). Um número alto, que abrange cerca de $24 \%$ da população total do país.

\section{Um muro entre o funcional e o simbólico - uma leitura particular}

Uma leitura dessa problemática territorial, realizada pela geógrafa mexicana Norma Hernández ${ }^{73}$ atende parte importante dos objetivos explicitados na introdução deste trabalho. Portanto, optou-se por valorizar, nessa parte do artigo, algumas generalizações geográficas baseadas em uma leitura particular qualificadamente representativa. ${ }^{74}$

\footnotetext{
72 AZEVEDO, C. op cit .

${ }^{73}$ Norma Angélica Hernández Bernal foi, informalmente, entrevistada pelos autores desse artigo, no dia 02/07/2004. Norma é geógrafa pela Universidad Nacional Autónoma de México; Mestre em Geografia pela Universidade Federal de Minas Gerais (UFMG). Atualmente, está em fase de doutoramento em engenharia ambiental pela UFMG.

${ }^{74}$ As idéias abordadas nessa parte do trabalho estão fortemente condicionadas à premissa de que a busca do entendimento - mesmo que preliminar e parcial da realidade concreta - de alguns aspectos da fronteira MEX-EUA tende a (re)constituir, ao menos, uma percepção imanente das questões que permeiam essa realidade objetiva. Sendo assim, torna-se coerente assumir a perspectiva de que sonhos individuais, angústias, idiossincrasias ou lembranças negativas de determinados processos sociais, por exemplo, podem ser ocultados, mas não serão psicologicamente abolidos. Soma-se a esse princípio, a idéia de que a autorestrição, a censura institucionalizada, ou mesmo, a opacidade "intrínseca" de determinados fatos podem sofrer, muitas vezes, rupturas por meio do exercício do intelecto. Por outro lado, é importante frisar que a reciprocidade de perspectivas entre os sujeitos e objetos transcende, evidentemente, a natureza inteligível da razão. Sobre proposições gerais e percepções individuais e coletivas ver RUSSELL, B. Ensaios escolhidos Bertrand Russell. SP: Nova Cultural, 1992.
}

Cadernos do Leste

Artigos Cientificos

Belo Horizonte, Edição Especial, 2000 a 2008 
Segundo Norma Hernández, há um sentimento coletivo no México em relação a construção do muro fronteiriço: "nós, mexicanos, nos sentimos agredidos, rejeitados, vítimas de um preconceito histórico."

Evidentemente que o Muro adquire valores diferentes para uma população de 103 milhões de mexicanos ${ }^{75}$. E não se trata apenas da questão numérica. Visões ideológicas divergentes entre indivíduos ou grupos sociais, por exemplo, reforçam a afirmativa na direção da diversidade. São normais as variações de sentimentos em relação ao Muro e é bastante provável que milhares de mexicanos sejam, inclusive, racionalmente favoráveis ao controle efetivado pelo SIN (Serviço de Imigração e Naturalização) dos EUA. Portanto, como já mencionado, a valiosa leitura de Norma Hernández trata-se, assim, de uma generalização circunscrita na sua visão particular de mundo que, inevitavelmente, é influenciada pela sua relevante formação geográfica.

No que se refere ao "preconceito histórico", por ela destacado, é sobejamente sabido que, nos EUA, as discriminações raciais constituem problemas sociais graves, muitos inclusive originados no período colonial. Entretanto, na fronteira MEX-EUA, discriminações raciais assumem formas de crimes hediondos. De acordo com Norma Hernández,

“(...)os migrantes sofrem maus-tratos o tempo todo. Ao ultrapassar a fronteira, quando não morrem por inanição ou desidratação, são envenenados por galões de água contaminada. Ao chegar, são hostilizados no trabalho. São desrespeitados de todas as formas possíveis, o esforço desses trabalhadores mexicanos não é valorizado."

Importante esclarecer, com base no depoimento de Norma, que ao longo do território fronteiriço (que abrange as regiões desérticas), inicialmente, tambores com água eram deixados por alguns cidadãos estadunidenses que tentavam, assim, minimizar o sofrimento de alguns migrantes clandestinos. Entretanto, posteriormente, prevaleceu o sentimento xenófobo de outros estadunidenses em relação aos mexicanos. A água de vários desses tambores começou a ser envenenada. Valores de solidariedade humana, que se

75 www.amcham.com.br $-02 / 02 / 2005$.

Cadernos do Leste

Artigos Científicos

Belo Horizonte, Edição Especial, 2000 a 2008 
desenvolviam na fronteira foram, infelizmente, sendo suplantados por determinadas atitudes racistas e criminosas. $^{76}$

Ainda sobre o preconceito, Cardoso (2002) defende que "o pragmatismo parece estarse sobrepondo ao preconceito". ${ }^{77}$ Para ele,

"Estatísticas recentes apontam que a população de origem mexicana que vive nos Estados Unidos é de 20,6 milhões de pessoas dos quais até 5 milhões estão ilegalmente. Por mais paradoxal que possa parecer, empresários americanos têm cruzado a fronteira em busca de empregados." 78

Interesses econômicos, neste caso, são hierarquicamente colocados na frente de qualquer concepção etnocêntrica, mas é preciso ainda, nesse contexto, distinguir mão-de-obra (qualificada ou não) de ser humano ${ }^{79}$. A afirmativa anterior de Norma Hernández sintetiza muito bem a posição de parte do empresariado estadunidense que "recruta" o migrante mexicano para o trabalho e, ao mesmo tempo, nega-o como pessoa.

Norma Hernández ressalta que o NAFTA apresenta várias contradições ao permitir a livre circulação de mexicanos para o Canadá, mas há negação de livre circulação de mexicanos para os EUA. A criação do NAFTA, segundo Cardoso (2002), produziu maior riqueza no norte do México, mas estimulou a saída do mexicano do próprio país: “(...) concomitante à liberalização da circulação de bens, incrementou-se as restrições ao trânsito de pessoas entre os dois países."

\footnotetext{
${ }^{76}$ A ação coletiva de moradores estadunidenses, conhecida pela denominação Lights in the Nights, de ocorrência, principalmente, nos estados do Arizona, Novo México e Califórnia objetiva dificultar, pelo menos por algumas noites, a entrada de mexicanos ilegais.

${ }^{77}$ CARDOSO, A. op. cit. p. 116.

${ }^{78}$ Ibidem, p. 116. Ainda segundo Cardoso, “A mão-de-obra mexicana faz-se presente em diferentes setores da economia dos Estados Unidos, da agricultura à construção civil, passando pelo processamento de alimentos e até mesmo ocupando cargos em empresas de alta tecnologia". (Idem. p. 116).

${ }^{79}$ Com base na frase do escritor alemão Max Frisch: "Importamos mão-de-obra, recebemos seres humanos". Ver Cardoso op. cit. p. 113.

${ }^{80}$ CARDOSO, A. op. cit. p. 116. As contradições manifestam-se, por exemplo: a) na diferenciação destacada por Norma, ou seja, do direito atribuído ao mexicano de migrar livremente para o Canadá mas não para os EUA; b) na ação de controle fronteiriço do Estado em relação aos interesses de determinados grupos de empresários estadunidenses que almejam a mão-de-obra mais barata; c) no fato de que essa restrição (e o controle da fronteira) à livre circulação de mão-de-obra incrementou significativamente o contingente de trabalhadores ilegais nos EUA, o que é, de certa forma, desejado por alguns setores empresariais, mas
}

Cadernos do Leste

Artigos Científicos

Belo Horizonte, Edição Especial, 2000 a 2008 
Segundo Norma, o Estado mexicano tem sido conivente com os conflitos existentes na fronteira e, também, com o aumento de migrantes clandestinos nos EUA ${ }^{81}$. De acordo com a geógrafa, depois do governo de Salinas (final dos anos de 1980 e início dos anos de 1990) o "pacto silencioso" entre o Estado e as migrações ilegais aprimorou-se devido, principalmente, à importante circulação de dinheiro na fronteira. Cardoso (2002) salienta que "as remessas de dinheiro para o país natal, de mexicanos que trabalham nos Estados Unidos, somou no primeiro trimestre de 2001 a cifra de US\$2,1 bilhões, sendo importantíssima fonte de renda do México". ${ }^{2}$

Destaca-se que o processo de transferência de dólares para o MEX passou a ser, em grande medida, formalmente controlado por empresas particulares:

“(...) um em cada vinte lares é favorecido pelas remessas dos imigrantes. Essa imensa soma era transferida para o México, até 1998, através de correios e telégrafos. Com a abertura econômica, duas empresas privadas Money Gram e Western Union, tomaram conta das remessas, ganhando altas comissões, cerca de 1,2 bilhões de dólares por ano". ${ }^{83}$

Para Cardoso (2002), à medida que são reforçados mecanismos de contenção na fronteira, novas redes clandestinas formam-se desafiando, assim, os obstáculos legais.

"Ganha destaque a ação dos "coyotes" (homens que se especializam em burlar os controles da fronteira e facilitar a entrada de imigrantes ilegais no país destino). No ano de 2000, registrou-se a morte de 491 mexicanos no espaço fronteiriço (...)Cada imigrante ilegal paga - antecipado - aos “coyotes" algo em torno de US\$2.500 pelos seus "serviços"”. ${ }^{84}$

Sobre a crescente migração de mexicanos em direção aos EUA, Norma Hernández destaca a causa econômica como sendo um dos principais motivos: "é evidente que essas

abominado por outros grupos (como o de alguns trabalhadores estadunidenses que alegam que tal processo tem aumentado o desemprego formal). Sobre os itens b e c, ver Cardoso (2002) op. cit.

${ }^{81}$ Há conivência, apesar do acordo firmado em junho de 2001, entre os EUA e MEX, que permite às autoridades estadunidenses revisar as operações de controle na fronteira demovendo a população, inclusive, da vontade de ultrapassá-la. Ver Cardoso op. cit. p.116.

${ }^{82}$ CARDOSO, A. op. cit. p. 116.

${ }^{83}$ CADERNOS DO TERCEIRO MUNDO. N 217; P. 47; “Os dólares dos imigrantes". Fevereiro/março de 2000.

${ }^{84}$ CARDOSO, A. op. cit. p. 116.

Cadernos do Leste

Artigos Cientificos

Belo Horizonte, Edição Especial, 2000 a 2008 
migrações ocorrem por necessidades econômicas(...)" mas, acrescentou: "pode existir algo transcendental também...afinal, como é sabido, o sudoeste daquele país foi do México há algum tempo atrás. Existem grandes raízes culturais nessa região. Será que alguns migrantes se sentem com o direito de voltar para um lugar que já foi do México?”.

O fator econômico, de fato, constitui o motivo maior das migrações legais e ilegais dos mexicanos para os EUA. Entretanto, é provável também que parte do movimento migratório rumo a fronteira carregue em si comportamentos psicossociológicos relacionados ao passado territorial do México. Determinados grupos familiares, tradicionalmente, reproduzem essa aventura migratória através de gerações ${ }^{85}$. A hipótese de um movimento inconsciente pode ser acrescida a da necessidade econômica considerando-se, evidentemente, as variações para os diversos casos de migração do MEX para os EUA.

Questões como as seguintes estimulam a reflexão sobre algumas das diversas situações em que migrantes mexicanos podem, objetiva e/ou subjetivamente, se deparar:

- O que é ser mexicano (legalmente ou não) em território estadunidense ?

- O que é ser mexicano no México? O que é ser mexicano no México e "simultaneamente" em território estadunidense? (Em razão das migrações sazonais).

- Como é ser mexicano tendo em vista que, tradicionalmente, gerações migram para regiões dos EUA que já foram territórios mexicanos?

São muitas as formulações que podem ser elaboradas e, mais ainda, são as possibilidades de resposta. Uma situação, no entanto, que também merece atenção é a do imigrante que nega a sua identidade étnico-cultural (que pode às vezes coincidir com a sua identidade nacional). Nesse caso, pergunta-se: o que significa negar-se culturalmente em um país (EUA) onde ainda persiste, em vários segmentos da sociedade, um forte racismo?

\footnotetext{
${ }^{85}$ No inverno, as Borboletas Monarcas migram do Canadá para o México. Popularmente, os migrantes mexicanos são comparados a essas borboletas tanto em função da sazonalidade de determinadas migrações, quanto em relação a tradição migratória de algumas famílias (netos, por exemplo, reproduzindo sistematicamente o movimento migratório dos avós).
}

Cadernos do Leste

Artigos Cientificos

Belo Horizonte, Edição Especial, 2000 a 2008 
Complexos de inferioridade estão, muitas vezes, relacionados à incapacidade intelectual de situar-se psicogeograficamente no mundo. No caso em questão, o problema localiza-se, essencialmente, em conseguir, adequadamente, situar-se de maneira política enquanto pessoa, cidadão e imigrante. Essa incapacidade intelectual também aplica-se ao propósito de sequer aproximar-se da compreensão de posições racistas. Por outro lado, a posição econômica familiar ou individual, por exemplo, de um trabalhador mexicano em relação à maioria dos trabalhadores estadunidenses acaba por colocá-lo em situação de inferioridade (econômica) diante do "sonho americano". São muitas as fronteiras segregacionistas e, não raro são os casos em que não são os muros de concreto ou a força policial que constituem os maiores obstáculos a serem superados. Moura (2000), nesse aspecto, destaca Rivas: "Las fronteras de verdad son aquellas que mantienen a los pobres apartados del pastel." 86

No que se refere à eficiência do muro, a geógrafa afirmou:

“o muro não funciona. A cada dia centenas de pessoas conseguem ultrapassá-lo. O problema maior são as condições naturais da região da fronteira: o deserto árido, a sede, a fome, o cansaço(...)"

A citação de Hissa (2002), destacada logo no início desse trabalho, é convergente em relação à afirmativa de Norma. Reforça-se, então, a condição simbólica do muro enquanto uma barreira psicológica que suscita a ultrapassagem, a transgressão "libertadora". Por outro lado, como colocado anteriormente, as características fisiográficas - típicas de ambientes áridos - representam um obstáculo mais concreto para os migrantes clandestinos do que o próprio Muro.

\section{CONSIDERAÇÕES FINAIS}

Mais uma geopolítica estatal de segregação social converte-se territorialmente. De um lado, o muro estadunidense ofende e agride mas, por outro lado, representa força e segurança; inspira também desprezo e indiferença, ao mesmo tempo que atrai atitudes transgressoras.

\footnotetext{
${ }^{86}$ Rivas citado por Moura (2000) op. cit. p.98.

Cadernos do Leste

Artigos Cientificos
}

Belo Horizonte, Edição Especial, 2000 a 2008 
Símbolo de controle, de autoridade e de divisão unilateral, esse extenso muro não impede a ultrapassagem de migrantes clandestinos.

Nesta fronteira de tensão, os ventos de outono não são comunicados pelos “coyotes" e o deserto Mojave impõe-se mais francamente. A água envenenada dos galões do deserto não tem autoria e esse grave crime não se submete à infração da clandestinidade. O Rio Grande também contribui com a morte de sonhos que se afogam nas primeiras enchentes da primavera. Durante várias noites do ano, a polícia (a "border patrol”) é auxiliada pelas luzes da ignorância e do racismo.

No México, o "Estado da conciliação" articula-se no interior mais íntimo de interesses divergentes: a soberania nacional, o NAFTA, o "pacto anti-migratório" com os EUA, as divisas em dólares provenientes do trabalho clandestino, etc. $\mathrm{Na}$ "Fronteira Sul" o subimperialismo mexicano ergue um muro invisível, abstrato e subalterno. Como no Norte, a violência, a intolerância, a corrupção, o medo, a morte e a persistência se reproduzem. Da fronteira sul para a fronteira norte transitam "coyotes" e as polícias e, neste caso, a América Latina depara-se duplamente com a segregação, com a extorsão.

Nos Estados Unidos, alguns empresários capturam mexicanos ilegais "ignorando", assim, leis e discriminações raciais. A complexidade do Capital manifesta-se, inclusive, na relatividade da fronteira e no aumento da Mais-valia Absoluta. No grande muro de contenção da desordem, algumas fissuras mostram-se necessárias para manutenção da ordem estabelecida. Cinismo, hipocrisia e ideologias reforçam a estrutura desse muro.

Contudo, denúncias, esperança, resistência também marcam a sua história, bem como certos “desenhos de Berlim" comparecem de um lado do Muro e de outro, na Fronteira Norte e na Fronteira Sul. Prevalece, entretanto, a separação dos povos, das nações, dos mundos desiguais e combinados. Aprisionada nessas fronteiras, bloqueada pelo Muro ou esquecida no Deserto, a utopia aguarda silenciosamente a sua libertação.

Cadernos do Leste

Artigos Cientificos

Belo Horizonte, Edição Especial, 2000 a 2008 


\section{REFERÊNCIAS BIBLIOGRÁFICAS}

ANDRADE, M. C. A trajetória do Brasil (de 1500 a 2000). SP: Contexto, 2000. . Imperialismo e Fragmentação do Espaço. SP. Contexto, 1989.

AZEVEDO, C. O muro americano. IN: Revista Manifesto (edição no 0), São Paulo, Instituto Gutenberg, 1998.

CADERNOS DO TERCEIRO MUNDO, n² 221; RJ: junho/julho de 2000.

CADERNOS DO TERCEIRO MUNDO. N 217; P. 47; "Os dólares dos imigrantes". Fevereiro/março de 2000

CARDOSO, A. Migrações internacionais - os blocos regionais e a mobilidade mundial de mão-de-obra. IN: São Paulo em Perspectiva, ano II, nº 16, p.112-124, 2004.

CIMAC, 24 de junho de 2003, "Frontera sur de México: donde todo pasa, pero todos hacen como que no pasa nada." Por Soledad Jarquín Edgar, correspondente CIMAC. Disponível em: http://www.cimacnoticias.com - Claudia Smith, de Califórnia Rural Legal Assistence, com dados do Consulado Mexicano em San Diego, Califórnia. www.tij.uia.mx - 05/10/2004.

COSTA, Wanderley Messias. Geografia Política e Geopolítica. São Paulo: Hucitec/USP, 1992.

El Universal, 25 de março de 2004, "Guatemaltecos exigen a México respetar derechos Protestan en la Unión Americana por la militarización de la frontera con su país." Do Correspondente José Carreño. Disponível em: http://www.eluniversal.com.mx Enciclopédia Encarta 99 (CD ROM) Guia do Terceiro Mundo. RJ: Terceiro Mundo, 1984.

HAESBAERT, R. "Questões e mitos sobre a globalização" IN Fronteiras e espaço global. Porto Alegre, AGB, 1998.

HISSA, C. E. V. A mobilidade das fronteiras: inserções da geografia na crise da modernidade. BH: UFMG, 2002.

Instituto de Investigaciones Económicas - Universidad Nacional Autónoma de México. Chiapas. México, D.F.: Era, 1997.

Jornal la Mesa Nacional para las Migraciones en Guatemala (Menamig)

Cadernos do Leste

Artigos Cientificos

Belo Horizonte, Edição Especial, 2000 a 2008 
La Opinión, 29 de setembro de 2003, "Denuncian abusos en frontera sur de México" Repórter Jorge Morales Almada. Disponível em: http://www.laopinion.com

MARTIN, A. Fronteira e nação. SP: Contexto, 1998.

MASSAD, A. Sombrero na mão. IN: Revista FÓRUM, n ${ }^{\circ} 10$

MÉLO, J. L. B. Reflexões conceituais sobre fronteira. IN Fronteiras na América Latina Espaços em transformação. Porto Alegre: UFRGS / Fundação de Economia e Estatística, 1997.

México-EEUU: Este muro si"”: Por: Diego Cevallos/IPS. Publicado em 29 de outubro de 2003. IN: Asamblea Popular Revolucionaria http://www.aporrea.org (artículo).

Ministerio de Educación Pública. Límites entre Guatemala y México. Guatemala, Centro Editorial "Jose de Pineda Ibarra", 1964.

MIYAMOTO, S. Geopolítica e poder no Brasil. SP: Papirus, 1995

MOURA, R. Fronteiras invisíveis: o território e seus limites. IN: Território/LAGET, UFRJ ano $\mathrm{V}, \mathrm{n}^{\circ} 9-\mathrm{RJ}$ : UFRJ, 2000.

MOURA, R. Dos espaços sem fronteiras às fronteiras dos espaços. IN Fronteiras na América Latina - Espaços em transformação. Porto Alegre: UFRGS / Fundação de Economia e Estatística, 1997

PIRES, H. F. "Ethos" e mitos do pensamento único globaltotalitário. SP: AGB; Terra Livre; $\mathrm{n}^{\circ} 16,2001$.

POMER, L. As independências na América Latina. SP: Brasiliense, 1981.

RAFFESTIN, C. Por uma geografia do poder. SP: Ática, 1993.

RUSSELL, B. Ensaios escolhidos Bertrand Russell. SP: Nova Cultural, 1992.

SOUZA, M. J. L. O território: sobre espaço e poder, autonomia e desenvolvimento. IN Geografia : conceitos e temas. RJ: Bertrand Brasil, 1995.

Un especial de National Geographic sobre uno de la inmigración de los indocumentados. Redacción. 22/03/ 2004 
WEBER, David J. La frontera norte de México, 1821-1846: El sudoeste norteamericano em su época mexicana. Madrid: Editorial MAFRE, 1992. 